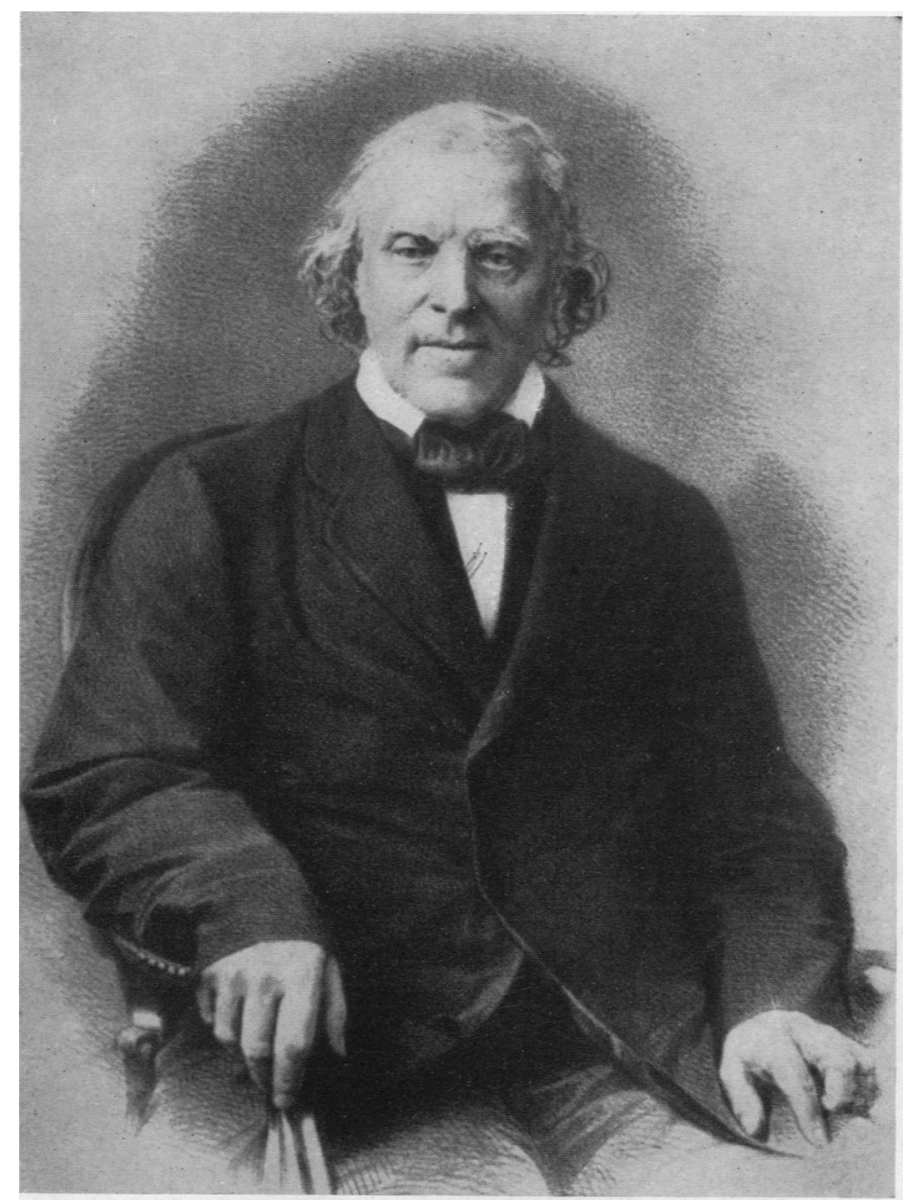

Francois-Vincent Raspail 1794-1878

"The founder of histochemistry"

\title{
A REVIEW OF MODERN METHODS IN HISTOCHEMISTRY
}

BY

\section{A. G. EVERSON PEARSE}

From the Department of Pathology, Postgraduate Medical School of London

(RECEIVED FOR PUBLICATION JANUARY 2, 1951)

ThIS Review is divided into two sections; the first is purely historical, and the second documentary and descriptive in its treatment of modern histochemical methods. Examples of the employment of such methods are given in the second section immediately following the methods to which they refer. The word " modern," in respect of any particular method, refers to usage rather than to origin; nevertheless, a number of the more important methods of which I propose to treat are modern in origin and even ultra-modern in usage. 


\section{The History of Histochemistry}

It is not easy to write the history of a science which one of its chief exponents (Lison, 1936) believes to have arisen de novo, and which many of its supporters consider an invention of the twentieth century. In spite of this we need not doubt that histochemistry began long before 1900 , and, taking the subject of the chemistry of the tissues in its broadest sense, we can build up a picture of the journey from its origins in the isolated, unconnected reports of the early nineteenth century down to the comprehensive and expanding science of the present day. The brief tabulated history which appears below is by no means complete; it forms a skeleton on which to hang the otherwise unconnected individual references which follow.

1800-29.-Histochemistry was unknown as a separate science and scarcely practised.

1830-55. - These years saw the beginnings of histochemistry as a science. (Raspail's Essai de Chimie Microscopique Appliquée à la Physiologie, 1830, and Nouveau Système de Chimie Organique, 1833; Lehmann's Lehrbuch der physiologischen Chemie, 1842; Raspail's New System of Organic Chemistry, 1834, in translation.)

1856-71. - Histochemistry was mainly biological chemistry, and most of its methods involved tissue destruction. Textbooks on histochemistry began to appear. (Physiological Chemistry of Lehmann, 1851, in translation; Chimie Anatomique of Robin and Verdeil, 1853; Chemie der Gewebe des gesammten Thierreichs of Schlossberger, 1856. Handbuch der Histologie und Histochemie des Menschen of Frey, 1867. The first use of aniline dyes in histology was described by Bencke in 1862.)

1872-98. - Part of histochemistry left histology and became attached to physiology, and part remained as biological chemistry. (Ein Beitrag zur Histochemie, Miescher, 1873; Histology and Histochemistry of Man, Frey, 1874, in translation; Traité de Chimie Physiologique of Lehmann, 1883, in translation; and Bunge's Lehrbuch der physiologischen und pathologischen Chemie, 1887.)

1899-1929.-The first quarter of the twentieth century saw the rapid expansion of descriptive histopathology. Histologists were concerned with new dyes and staining techniques, and showed less interest in the chemistry of tissue structures. The study of mammalian micro-anatomy was "almost complete" according to Mann. Macallum's Methoden und Ergebnisse der Mikrochemie, 1908, and Mann's Physiological Histology, 1902, described microchemistry and microphysiology. Other works of this period were the Review of Recent Developments in Histochemistry, by Parat, 1927; Animale Histochemie, by Patzelt, 1928; Praktikum der Histochemie, by Klein, 1929; and Histochemische methoden, by Hertwig, 1929.

1930-44. - This stage saw the rebirth of histochemistry and its partial return to the domain of histology. (Handbook of Chemical Microscopy, Chamot and Mason, 1930; Histochemische methoden of Romeis, 1932; Die Mikroveraschung als histochemische Hilfsmethode, by Policard and Okkels, 1932.) The most important work was Lison's Histochimie Animale (1936) in which the author proclaimed the new science of histochemistry without tissue destruction.

1945-50.-Since the war there has been considerable expansion of histochemistry and histophysiology by new techniques (Linderström-Lang, Problems in Histochemistry, 1936; Techniques of Histo- and Cyto-chemistry, Glick, 1949), and the 
closing years of this half-century have seen the increasing application of histochemistry to histological and pathological problems.

Baker $(1943,1945)$ in a fascinating and valuable monograph, and in his book on cytological technique, has drawn attention to the claims of the French microscopist F. V. Raspail to be considered as the founder of histochemistry, and, since the priority and comprehensiveness of these claims are unassailable, his name and portrait head this review as reminders of the ancient origin of the youngest of the pathological sciences. Although earlier references to histochemical practice can be found, such as the use of solutions of iodine for the staining of starch, first described as a reaction by Colin and de Claubry in 1814 and employed in a microscopic study of starch grains by Caventou in 1826, the first clear appreciation of the science of microscopic tissue chemistry came from Raspail (1825a and b; 1829). This author, besides using solutions of iodine as a means of indicating starch in vegetable tissues, produced an aldehyde method for determining protein in the tissues which, modified by many workers since this time, is still applied in histochemistry as the Voisenet-Fürth reaction for tryptophan. Raspail also discovered and applied the xanthoproteic and Liebermann (1887) reactions for protein and tested the reaction of protoplasm with a blue dye obtained from a species of sun spurge, found in the Mediterranean, which turned pink in acid solution. For further information about the astonishing histochemical researches of Raspail, the reader is referred to the original papers, some of which have been translated into English.

Following the initial overtures of Raspail, progress in histochemistry was slow, and very little work which can be described as histochemical, even in the broadest sense, was recorded until after 1860 .

Among the oldest histochemical techniques are those for demonstrating iron, and some of these had their origin in the work of Vogel $(1845,1847)$, who detected iron in the tissues by its conversion to black ferrous sulphide with yellow sulphide of ammonia. In 1867 Perls introduced his Prussian-blue method for demonstrating iron, which remains the method of choice up to the present day. Perls was followed in 1868 by Quinke, who used Vogel's sulphide method. This method also survives to the present day practically unmodified. In 1844 Millon described his reaction for proteins which Hoffmann, in 1853, applied to the characterization of tyrosine. Not until 1888 was the method used in histochemistry, by Leitgeb, although Payen (1843) demonstrated nitrogenous substances in vegetable tissues with mercury proto-nitrate. In 1850, though the result was not published until 1859, Claude Bernard performed his celebrated experiment by the injection into dogs of iron lactate and potassium ferrocyanide, locating the resulting Prussian blue, which developed in the presence of acid, not in the gastric glands but only on the surface of the gastric mucosa. Though in vivo techniques are more truly physiological, this particular example may justly be claimed for histochemistry. In 1861 occurred the first reported use of enzymes for tissue digestion which developed, by the end of the century, into the well-recognized technique of enzymal analysis for cytochemical purposes (Kossel and Mathews, 1898). Beale (1861), who was the first exponent of this method, used gastric juice in order to remove unwanted tissues in his study of nerve fibres. As such, the technique was really micro-anatomical. Klebs in 1868 and Struve in 1872 showed that tincture of guaiac gave a blue colour with pus, thus first recording the presence of peroxidases, now well known to occur in the granules of the leucocytes. Brandenburg (1900) 
first demonstrated the peroxidase reaction in the latter site, and Ehrlich (1885) performed the "nadi" reaction in vivo by injecting alpha naphthol and paraphenylenediamine into animals and observing the formation of indophenol blue. This reaction is now known to denote cytochrome oxidase.

During the next period the work of Schultze (1861), in particular, stimulated histologists to investigate the nature of intracellular tissue. Most of the resulting work cannot be regarded as histochemical. In 1868 Heidenhain showed that ergastoplasm, the deeply basophil substance at the base of secreting gland cells, contained a material which could be precipitated with acetic acid. This is now recognized as ribonucleic acid. In 1870 he described the development of a brown colour in certain structures subjected to treatment with salts of chromium, now known as the chromaffin reaction. The use of enzymes is further exemplified by the work of Miescher (1871), who employed pepsin to free nuclei from cytoplasmic material, and of Stirling (1875), who isolated elastic fibres by means of digestion with gastric juice. These were hardly histochemical techniques in the modern sense, but they serve to illustrate the destructive nature of much of the research into the chemistry of the tissues at that time. In 1873 Miescher isolated nuclear chromatin by making use of its selective affinity for methyl green, and Ehrlich, in 1878-9, observed the effects of heat coagulation in increasing the affinity of haemoglobin for nitro dyes. This last work finds a modern echo in the inquiry into the effects of denaturation on the combination of histochemical reagents with specific groups in the tissues. Cornil (1875) used methyl violet and was the first to note the pink metachromasia given by amyloid when stained with this dye. Flemming (1876) described a cement substance holding together the fibrils which compose the loose connective tissue bundles. This he considered to be of a mucinous nature. A great volume of modern work confirms these observations on the substance now supposed to be the mucopolysaccharide, hyaluronic acid. In 1883 Ehrlich, investigating cases of diabetes, described the use of watery solutions of iodine for the specific staining of glycogen in the tissues. He was not the first to use such a technique, being anticipated by Claude Bernard (1877) in his classical researches.

In the succeeding years a great deal of work was done on the nature of protoplasm, especially by Stöhr (1882), who, as the result of coagulation studies, concluded that a protein substance was present in gastric parietal cells, and by Flemming (1882), Kossel (1882, 1886), Altmann (1886, 1889), Schwarz (1887), and Mann (1890). Altmann, in 1889, developed his method of fixation by freezing and drying, which has become an important modern tool of histochemistry in the hands of Gersh (1932) and his successors. During the last two decades of the nineteenth century histochemistry was submerged in the mass of work arising from the discovery and use of new dyes and the subsequent evolution of new staining techniques. Among the latter, since they have now been realized to have histochemical importance, may be mentioned the anilin-violet method of Gram (1884) and also the myelin methods of Weigert (1884) and Marchi (1892). During this period a great deal of work was being done on the chemical nature of staining, much of which has a modern application in histochemistry. Amongst the works of particular merit are those of Griesbach (1886), who postulated that tissue-dye compounds should have properties differing from those of the free radical; of Unna (1887), who tried to confirm this; and of Lilienfeld (1893), who investigated the staining of mucins. Heine 
(1895) is also worthy of note; he observed that segments of chromatin were intensely stained by Millon's reagent and tried, unsuccessfully, to distinguish between nucleoproteins and nucleic acids using mixtures of methyl green and rubin S. In 1895 Macallum demonstrated that, after treatment with sulphuric acid, the nuclei were stainable by the usual methods for iron in the tissues. Since this time, the question of whether this iron is really present in the nuclei, or adsorbed from elsewhere, has been debated at length. The chemical theory of staining was strongly supported by Mathews (1898) in his experimental work with albumins and albumoses, and important researches into the nucleohistones were conducted by Saint-Hilaire (1898) who noticed, in evolving a method for uric acid in the tissues, that nuclei were occasionally stained. He concluded that the presence of histone was responsible for the positive nuclear reaction. Saint-Hilaire also showed that nucleohistones, precipitated in the tissues by acetic acid, were dissociable by means of dilute solutions of hydrochloric acid, leaving the histones in situ. Variations on this last theme are widely employed at the present time.

Progress in other methods is represented by the work of Hoyer (1890), who demonstrated metachromasia in the cells of the mucous salivary glands, and by Daddi (1896), who first used Sudan III to stain fat which, when subsequently ingested by animals, was demonstrated in the tissues by its red colour. Sudan IV was proposed as a fat stain by Michaelis in 1901. Before Hoyer's discovery, mucins were stained by techniques making use of their strong basophilia. List (1885) was the first to use Bismarck brown for this purpose, and the same dye, in alcoholic solution, was used by Hardy and Wesbrook (1895) to stain water-soluble mucoproteins and mucopolysaccharides. Enzyme methods are represented by the contributions of Mall (1891), who investigated the swelling of collagen in various solutions, and the action upon it of crude preparations of pepsin and trypsin. Among methods for revealing inorganic salts in the tissues may be mentioned the techniques of Molisch (1893), who stained tissue-iron by converting it to the red thiocyanate, and of Lilienfeld and Monti (1892), who evolved an ammonium molybdate technique for visualizing phosphate, principally in organic form in the nuclei. This method was subsequently modified by Pollacci (1900) and by numerous other workers up to the present time. Finally, though it steps just into the present century and out of history for the purpose of this review, the method for calcium in the tissues which remains in current use was described by von Kóssa in 1901.

When the nineteenth century came to a close, the majority of histologists were occupied in reaping the rich harvest presented by new developments in the art of staining, and few had time to spare for histochemistry. The subject remained for the most part in abeyance until its revival in the 1930s, and its establishment on a modern footing as an independent branch of histology by Lison with his great work Histochimie Animale. So much for the past: the present and future of histochemistry remain to be discussed in the succeeding section.

\section{The Practice of Histochemistry}

Histochemistry may be defined as the chemistry of the tissues, and cytochemistry as the chemistry of cells. In practice, in order to avoid the use of two words where one will suffice, the word histochemistry can be used to cover the properties of both cellular and extracellular material. If we accept that these properties are both 
structural and functional, then histochemistry can be extended to cover matters usually regarded as the province of the physiologists. From the point of view of the histologist and pathologist, however, it is necessary to contract this wider concept and to reintroduce a restricted one. In this restricted sense histochemistry is the investigation of tissue components by applying to microscopical preparations methods of physical and chemical analysis which do not damage the tissues in such a way as to make them unrecognizable. Such methods should be within the compass of all histologists. Only methods which come broadly within this scope are included in the review of the modern methods of histochemistry which follows. The majority can be applied by the histologist to the tissues which he is accustomed to study, subject only to suitable preparation of the material. Few can be described as easy, if easy is taken to mean free of trouble, but good histological staining is itself seldom achieved without considerable effort.

In one or two particular fields the advances achieved by the use of new methods during the past ten years have been spectacular. In others, the use of older methods has continued, often with improved interpretation, as the result of using a number of parallel tests instead of a single one. This principle should always be observed when the nature of any particular material is under investigation. Both the recent advances and some of the older methods will be referred to in this review, and they will be treated broadly under the headings of the various compounds or group of compounds to which they refer. The problems of fixation, and methods for demonstrating enzymes, will be considered in separate sections.

\section{Fixation}

No new methods of fixation have been evolved in recent years, but one method in particular, that of freeze-drying, has come into widespread use among histochemists. This method, which was first introduced by Altmann in 1889, depends on the freezing of small pieces of tissue in liquid oxygen, or in isopentane chilled to about $-165^{\circ} \mathrm{C}$. with liquid oxygen. By this process of rapid freezing all the water in the tissues is converted into ice with the minimum formation of tissuedisrupting ice crystals, which form when material is frozen at higher temperatures. The frozen tissues are then dried in vacuo over $\mathrm{P}_{2} \mathrm{O}_{5}$ for two to five days, being maintained during this period at between -35 and $-70^{\circ} \mathrm{C}$. The dried tissues, allowed to reach room temperature, are vacuum-embedded in paraffin and cut in the usual manner. It is necessary, before applying most histochemical or ordinary staining techniques to freeze-dried material, to precipitate the proteins in the sections, which are still quite unfixed. For this purpose absolute alcohol is commonly employed.

The method was of little practical use until Gersh (1932) produced the forerunner of all modern freeze-drying apparatus. Since this time its use has been reported by many authors. Scott (1933), Hoerr (1936), Scott and Williams (1936), Packer and Scott (1942), Gersh (1948), and Wang and Grossman (1949) describe the apparatus or the technique for using it, while the application of the method to various problems is discussed by Bensley and Gersh (1933a), Bensley (1933), Bensley and Hoerr (1934), Goodspeed and Uber (1934, 1935), Hoerr and Bensley (1936), Simpson (1941a and b), and others. Its main advantages are that ordinary fixation artifact is avoided; materials in the tissues, including inorganic salts, remain in 
those sites which they occupied in vivo. Moreover, these materials are not denatured or otherwise altered, and, for instance, the isoelectric point of proteins may still be determined by their minimum solubility in buffers (Catchpole, 1949; Gersh, 1949a). Exception must be made to this statement in respect of many tissue enzymes, which I have found to be reduced in strength by the low temperature involved. This view is contrary to that of Doyle (1950), who found that the peptidase activity of rabbit appendix, using alanylglycine as substrate, was unaffected by freeze-drying and paraffin embedding. The stage has now been reached at which quite a simple apparatus will suffice to give results such as those illustrated in Plate I, Fig. 4, and Figs. 7, 8, and 10. Pancreas, illustrated in Fig. 4, is one of the easiest tissues to freeze-dry, owing to its low water content; other tissues, with a higher water content, are more difficult, and testis is practically impossible.

As far as ordinary fixation is concerned, advances have been made in our knowledge of the fixation of glycogen, ribonucleoprotein, and mucopolysaccharides in particular. Deane, Nesbett, and Hastings (1946) suggested an improvement in the fixation of glycogen which involved the use of ice-cold picro-alcohol-formalin. Lison and Vokaer (1949) recommend for the same purpose either cold alcohol or a mixture of $96 \%$ alcohol saturated with picric acid (85 parts), formol (10 parts), and acetic acid (5 parts). This fixative is used at a temperature of $-73^{\circ} \mathrm{C}$., produced by an acetone-solid $\mathrm{CO}_{2}$ mixture. Polarization, that is to say, streaming of the glycogen granules to one pole of the cell, still occurs with Lison's method. It can only be avoided by the use of the Altmann-Gersh freeze-drying technique (Figs. 9 and 10). Vallance-Owen (1948) has done considerable service in pointing out that glycogen is quite as adequately fixed by formol-saline as by alcohol or picricalcohol mixtures. His work was done at room temperatures, however, so that some of the less highly polymerized forms of glycogen, which may be preserved by Lison's refinement, were presumably lost in the fixing fluid. This does not alter the importance of Vallance-Owen's work in showing that glycogen studies can quite well be made on material fixed in formalin. (See methods for glycogen.) The effect of fixatives on enzymal hydrolysis, particularly with ribonuclease, has been studied by Stowell and Zorzoli (1947) and by Tulasne and Vendrely (1947). Both conclude that many fixatives, including plain formalin, give adequate results, but the latter authors obtained the best results with Chabaud's (1942) fixative, which consists of formalin, alcohol, acetic acid, and phenol. Flemming's fluid (Kaufmann, McDonald, and Gay, 1948) and Carnoy (Kaufmann, Gay, and McDonald, 1950) are particularly recommended for the preservation of nucleic acids and proteins, the second fixative leaving them in a condition where they are readily attacked by various hydrolytic enzymes. Many enzymes, hyaluronidases for instance, attack formol-fixed tissues less readily than tissues fixed in non-formalin or alcoholic fixatives. Holmgren and Wilander (1937) first employed $4 \%$ basic lead acetate as a fixative for acid mucopolysaccharides, especially for studies on metachromasia. It has since been used for the same purpose by Sylvén (1941), in combination with formalin, but is not worth while for routine use.

\section{Methods for Simple Protein and Amino-acids}

Apart from the determination of the iso-electric points of freeze-dried proteins in situ, by minimum solubility, numerous workers have attempted to estimate the 
iso-electric point of fixed tissue proteins by controlled $p \mathrm{H}$ staining. Pischinger (1926, 1927) and Zeiger (1930) were the chief exponents of this method. Levine (1940), however, showed that the staining intensity of a protein in buffered dye solutions was dependent on the type of dye and the type of buffer as well as on the concentrations of these and the fixative employed. He rightly stated that the method could not be used for estimation of iso-electric points. It has, nevertheless, proved useful for distinguishing precisely between various substances which exhibit different degrees of basophilia, such as mucopolysaccharides and muco- and nucleo-proteins, and for estimating the degree of tissue basophilia (Dempsey and Singer, 1946; Dempsey, Bunting, Singer, and Wislocki, 1947; Dempsey, Singer, and Wislocki, 1950).

The older microchemical methods for demonstrating protein, e.g., Millon's xanthroproteic method, are still widely employed in histochemistry. They depend on the presence of tyrosine, or of phenolic compounds, and can be largely superseded by modern developments of the diazonium reaction which we owe to Danielli (1947, 1950a). This author, observing that the colour produced by the diazonium reaction for tyrosine, tryptophan, and histidine was too pale to be useful, substituted what I have called his coupled tetrazonium reaction. To the indifferently coloured proteintetrazonium compound formed in the first part of the reaction, by virtue of the remaining free diazo group, a variety of phenols or amines can be coupled. This process increases the final colour many times, and, since the product is not diffusible, localization is accurate. This method, together with blocking techniques which enable it to be used for distinguishing the three amino-acids separately, renders obsolete the older histochemical methods used for the same purpose.

Workable histochemical modifications of the Sakaguchi reaction for arginine have been evolved by Serra (1944) and by Thomas (1946). The former author's method is theoretically more desirable, and in practice gives a recognizable red with arginine combined in tissue proteins. The specificity of the method is high, but the stability of the colour developed is not. The maximum colour developed during the reaction can seldom be maintained until the stage of examination under the microscope. The method is discussed by Baker (1947), who gives his own modification, and is recommended by Serra (1946) for demonstrating the presence of basic proteins by virtue of their high arginine content.

Three new methods have been evolved for the histochemical demonstration of compounds containing thiols (SH groups) such as cysteine for instance, and these should ultimately replace the deficient nitroprusside and lead acetate methods. They are the thiol-selective coloured organic mercurial method of Bennett (1948) and Bennett and Yphantis (1948), the aldehyde method of Danielli (1950a), and the blocking technique using dinitrofluorobenzene, also developed by Danielli. The last two reactions are as yet imperfectly worked out, according to their originator, but Bennett (1948) describes the successful use of his mercurial reagent for the demonstration of SH groups in biological materials.

\section{Methods for Nucleic Acids and Nucleoproteins}

In spite of doubts cast upon its specificity, the classical Feulgen reaction (Feulgen and Rossenbeck, 1924) continues to be employed for the cytochemical localization of thymonucleic (desoxyribonucleic) acid. These doubts have been raised, and sustained, by the work of Choudhuri (1943), Stedman and Stedman (1943a and b, 
Fig. 7.-Rabbit kidney. Freeze-dried, paraffin embedded, cut at $6 \mu$, fixed in $2 \%$ osmic acid. Rod-shaped mitochondria in the primary convoluted tubules and their occasiona palisade-like arrangement are notable, as is the apparent absence of lumen in many of the tubules. Haemalum and eosin $\times 550$.
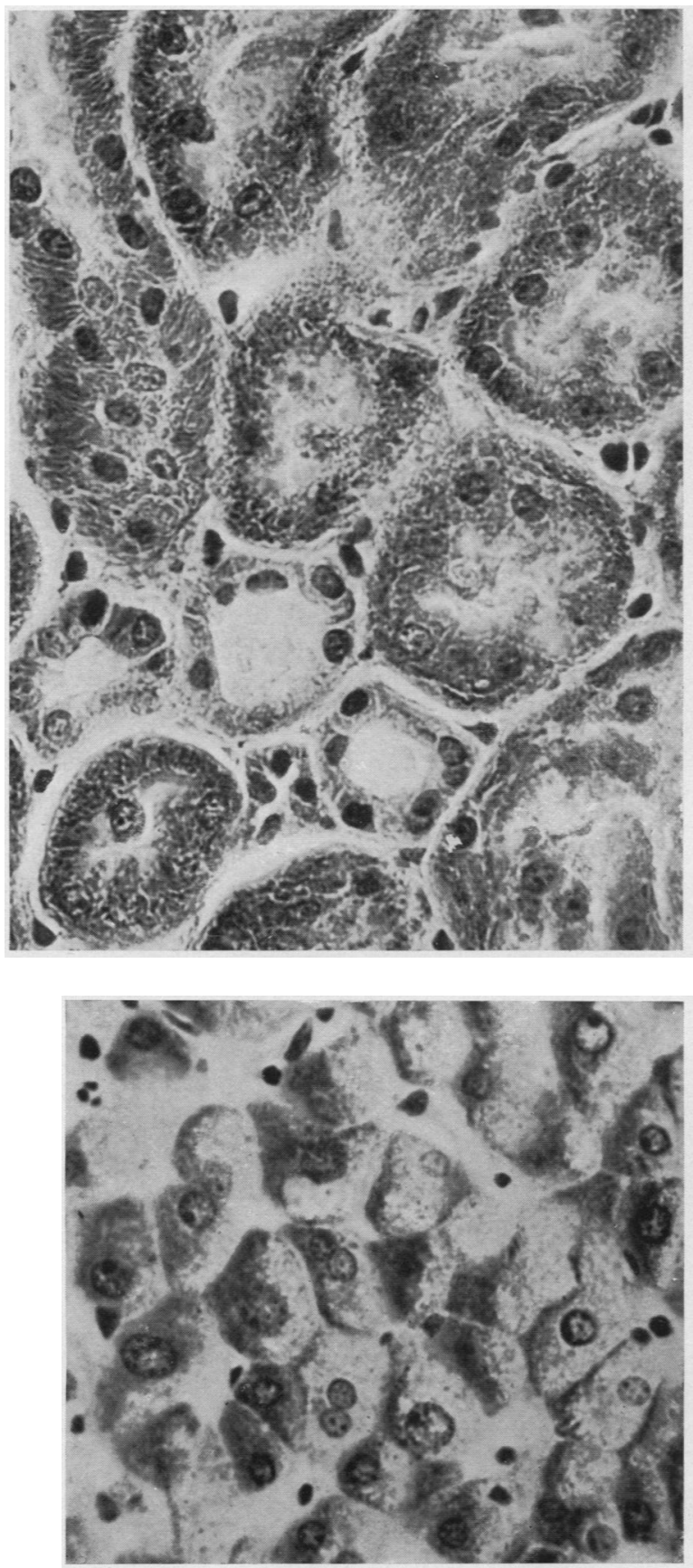

Fig. 9.-Human liver (biopsy specimen). Fixed in alcohol. Polarization of glycogen due to streaming artifact. Best's carmin, haemalum $\times 460$.

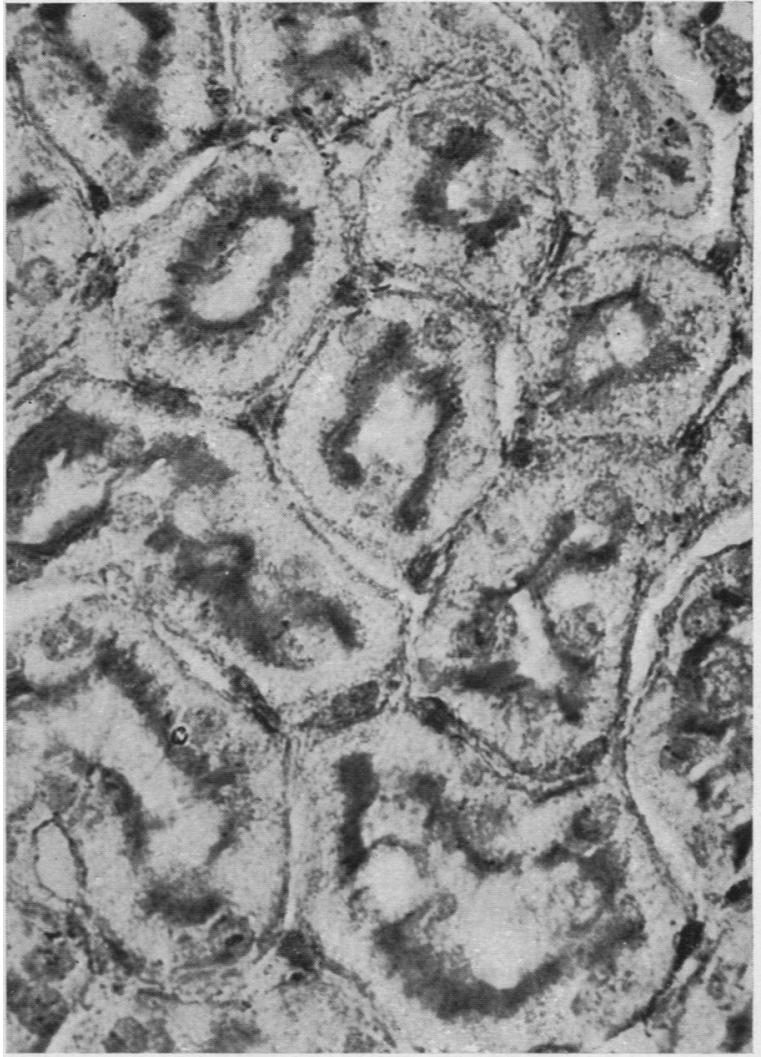

Fig. 8.-Rabbit kidney. Freeze-dried, paraffin embedded, cut at $6 \mu$, fixed in cold acetone. Three-hour incubation with $\mathrm{M} / 200$ phenyl phosphate at $p \mathrm{H} 9.0$. To show alkaline phosphatase concentrated in the brush borders of the tubules. Nuclei counterstained with carmalum. $\times 550$.

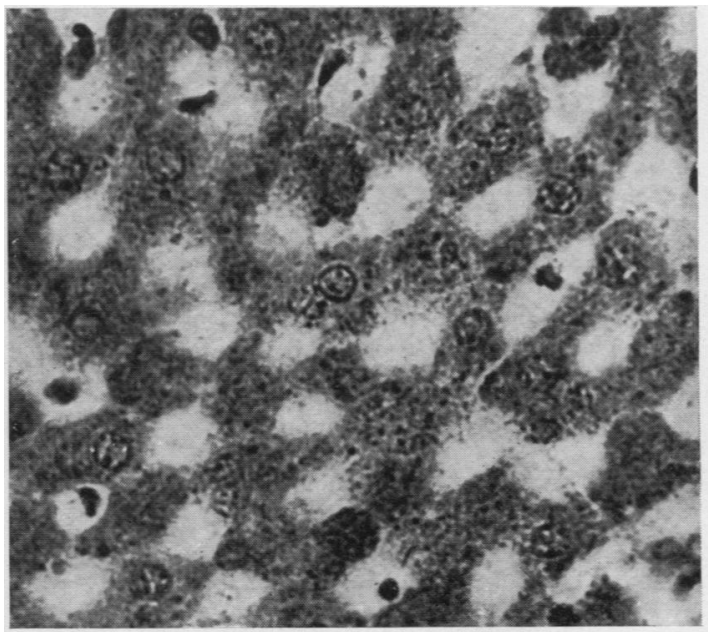

FIG. 10.-Rabbit liver. Freeze-dried, fixed in alcohol. Granules of glycogen are distributed throughout the cytoplasm of the cells. Best's carmine, haemalum $\times 460$. 


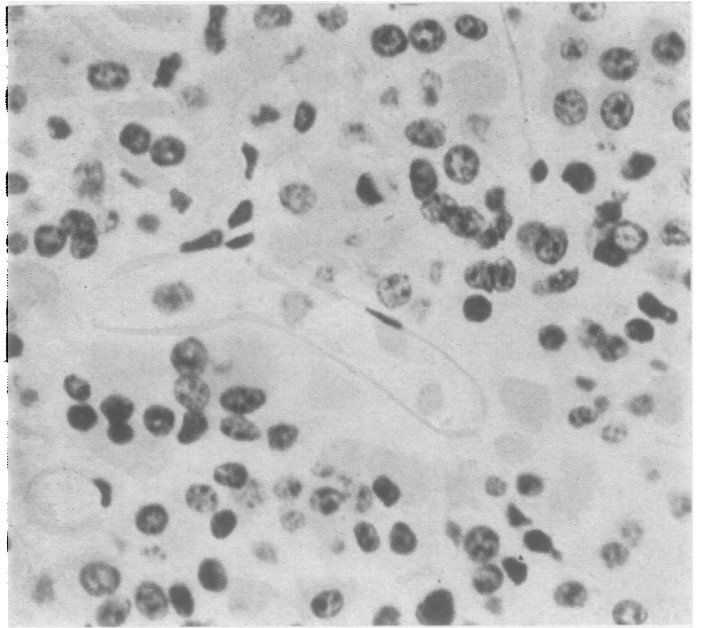

FIG. 11.-Nuclei stained by the Feulgen method for thymonucleic acid (Schiff's reagent after $N \mathrm{HCl}$ at $60^{\circ} \mathrm{C}$. for 8 minutes). Only the chromatin is stained. $\times 520$.
1944), Carr (1945), and Sibatani (1950). These authors believe that the aldehyde-leucofuchsin compound, formed when thymonucleic acid is treated by acid hydrolysis followed by Schiff's reagent, is diffusible, and that it becomes attached to various protein components of the nucleus. On the other hand, a great deal of evidence has been marshalled in support of the specificity of the reaction by Brachet (1946), Dodson (1946), Stacey, Deriaz, Teece, and Wiggins (1946), by Stowell (1946), and, most recently, by $\mathrm{Di}$ Stefano (1948), Chong-Fu Li and Stacey (1949), and Overend and Stacey (1949). The latter authors have tried to dispose of the Stedmans' objections

by showing that the highly polymerized residue of sperm desoxyribonucleic acid, after the extraction of purines by acid hydrolysis, reacts instantaneously with Schiff's reagent while the supernatant fluid remains colourless for as much as 24 hours. The results obtained by Stedman and Stedman (1950) contradict Stacey's findings. Histochemically the specificity of the Feulgen reaction can be controlled by making use of other reagents for revealing the aldehyde groups produced in the nuclei by mild acid hydrolysis. The results of such a procedure are shown below. Figs. 11 and 12 are of serial sections (though not serial fields), the first stained by the Feulgen reaction (de Tomasi's modification, 1936), and the second subjected to the same acid hydrolysis but treated subsequently with a hydrazide reagent described by Camber (1949) for the localization of ketosteroids (q.v.). This reagent combines with aldehydes as well as ketones, and the resulting compound is revealed by subsequent coupling with tetrazotized dianisidine in alkaline solution, a dark, purplish-blue colour being developed. By this method the localization of chromatin staining in the nuclei is precisely

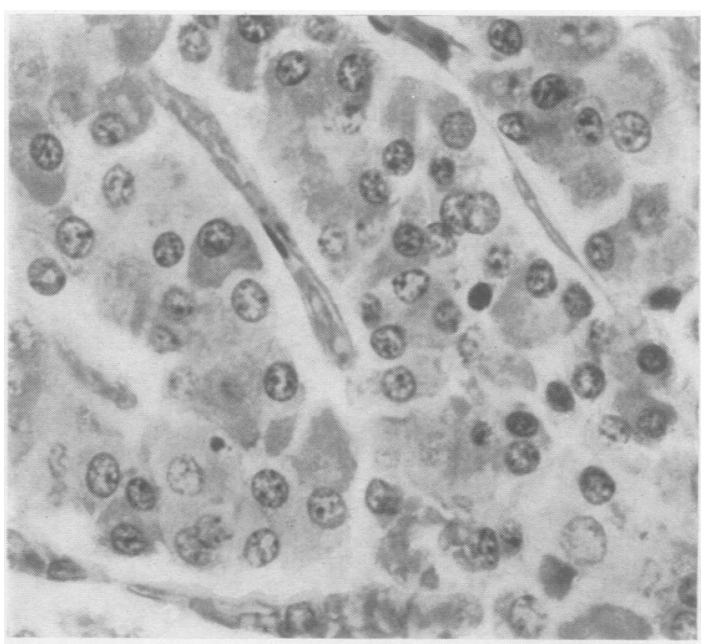

FIG. 12.- Serial section to Fig. 11. Nuclei stained by 2-hydroxy-3-naphthoic acid and diazotized dianisidine after $N \mathrm{HCl}$ at $60^{\circ} \mathrm{C}$. for 8 minutes. Chromatin purple, cytoplasm pink. $\times 520$. 
Fig. 14-Human adrenal gland. Frozen section, $10 \mu$, mounted in chrome glycerin jelly. Stained by a method reputed to be specific for ketosteroids. A positive reacition is seen in cells of the zona fasciculata. Ashbel-Seligman method $\times 335$.

Fig. 15.-Human skin. Resistance of collagen and reticulin (but not elastin) to the process of benzoylation. Coupled tetrazonium reaction $\times 235$.

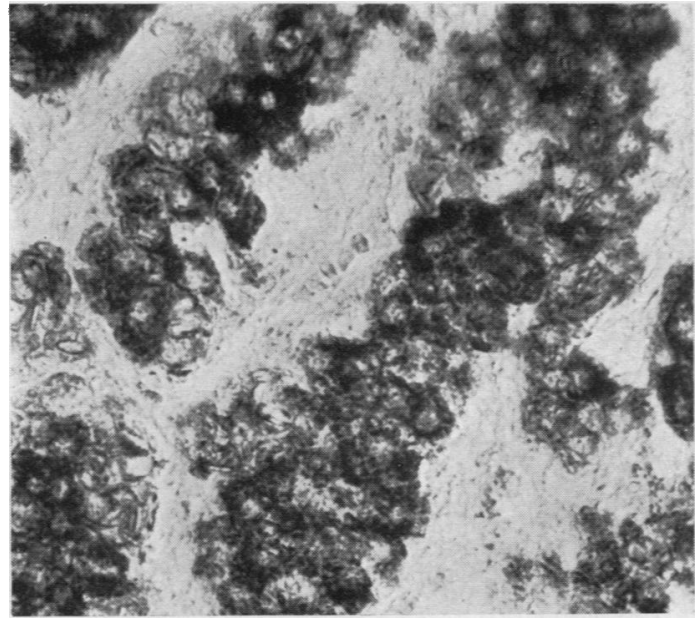

Fig. 14

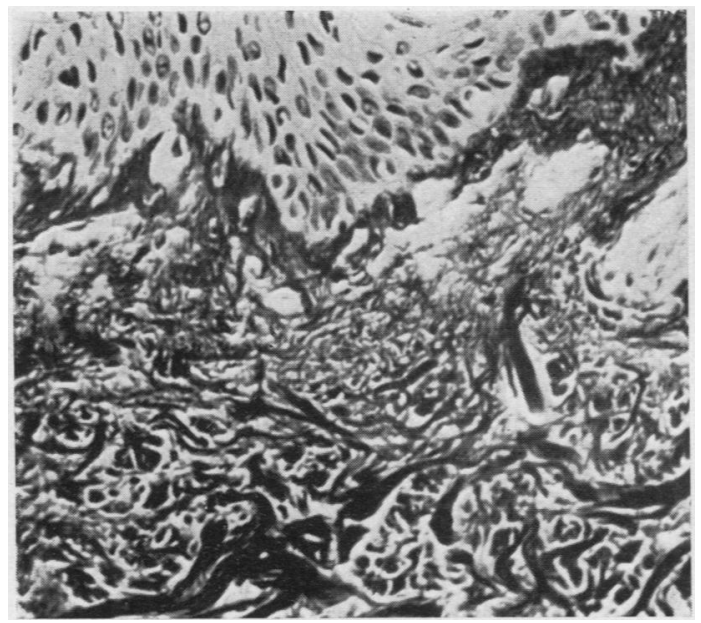

FIG. 15

FIG. 16-Human tongue. Striated muscle fibres, showing the P.A.S.-positive A bands. Periodic-acid-Schiff, celestin blue-haemalum $\times 490$.

FIG. 17.-Human tongue. Material in the A bands of striated muscle stained after benzoylation. The thinner $\mathrm{Z}$ lines were unstained and appear in the photograph because of their refractile properties. Coupled tetrazonium reaction $\times 1,150$.

FIG. 18.-Human anterior hypophysis. Specific staining of the beta granules after the application of moderate heat followed by 18 hours' benzoylation. Coupled tetrazonium reaction $\times 550$.

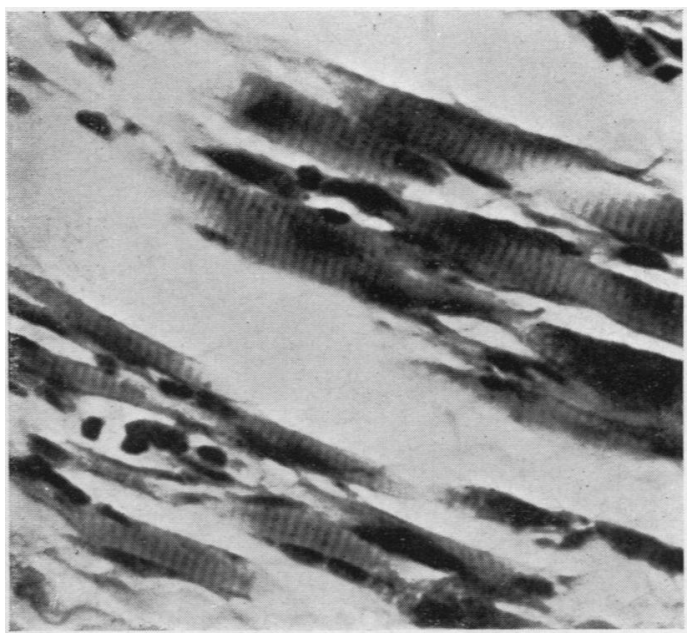

FIG. 16

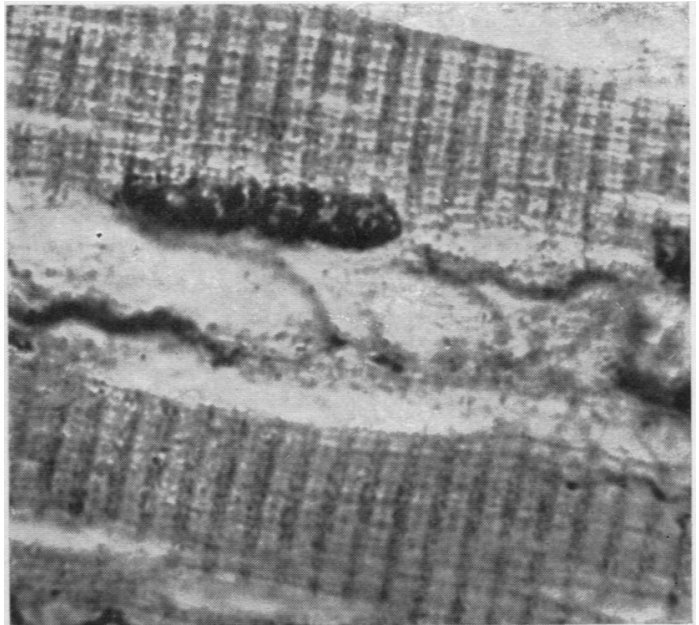

Fig. 17

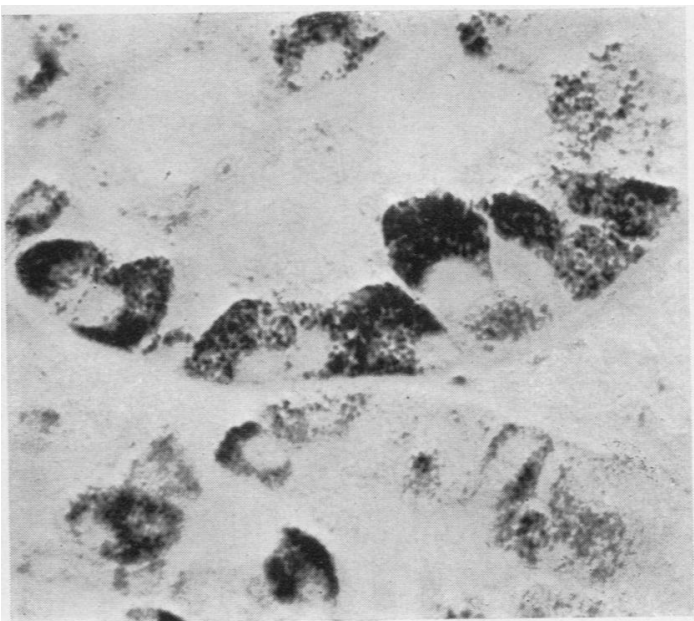

FIG. 18 
similar to that shown by the Feulgen reaction. Cytoplasmic detail is visible in Fig. 12 because the hydrazide reagent combines with tissue proteins by virtue of other groups in its molecule and the subsequent treatment imparts a pinkish colour to these protein-hydrazides. A useful modification of the Feulgen technique is described by Rafalko (1946).

The ordinary methods for staining both desoxyribose and ribose nucleic acids depend on the presence of the phosphate ion which confers their characteristic basophilia. Following the example of Brachet $(1940,1942)$ it is customary to use methyl green-pyronin mixtures for staining and distinguishing between the two types of nucleic acid. After ribonuclease Brachet and other workers have also used toluidine blue, alone or followed by an acid dye, for the purpose of demonstrating both ribonucleic and desoxyribonucleic acids. Material which stains with toluidine blue after ribonuclease is not ribonucleic acid. Both nucleic acids may also be localized by methods making use of their purine and pyrimidine content. Advantage may be taken (Mitchell, 1942; Danielli, 1947) of the fact that purines and pyrimidines react positively in the tetrazonium method already described for tyrosine, tryptophan, and histidine. The reaction with these amino-acids is first prevented by benzoylation or acetylation, after which only the purines and pyrimidines react. Benzoylation is carried out in $10 \%$ benzoyl chloride in dry pyridine at room temperature, acetylation with acetic anhydride in dry pyridine at about $100^{\circ} \mathrm{C}$. Plasma cell nuclei stained by this method are illustrated in Fig. 13. It is not so useful for cytoplasmic ribonucleotides since these are largely removed by benzoylation. The phosphate ion can also be demonstrated, after its release by nuclease treatment or prolonged acid hydrolysis, by combination in situ with ammonium molybdate after the manner of Serra and Queiroz Lopes (1945). These authors employ benzidine in place of the more usual stannous chloride as reducing agent for the phosphomolybdate produced in the first

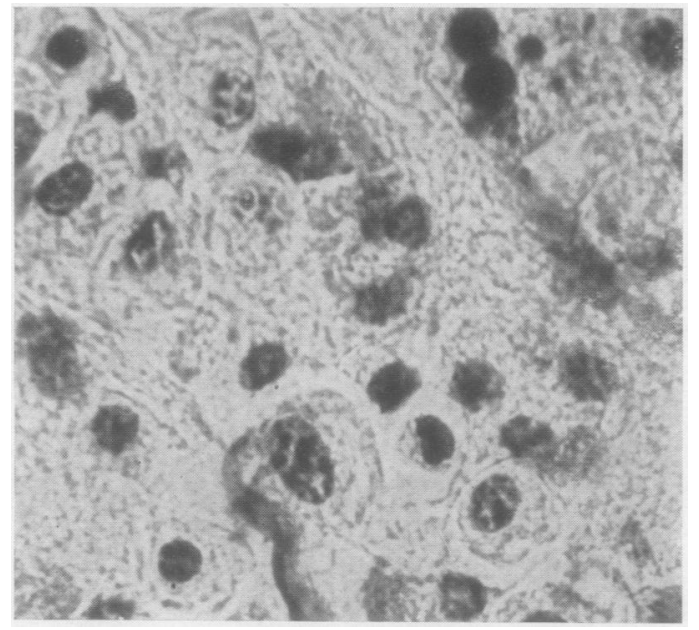

Fig. 13.-A group of plasma cells and, at upper right, three Russell bodies. Simple protein, as well as mucoprotein, Russell bodies stain positively by this technique. Fourteen hours' benzoylation at $22^{\circ} \mathrm{C}$. Coup!ed tetrazonium reaction $\times 700$. part of the reaction. Of methods demonstrating nucleic acid by virtue of the sugar moiety, Feulgen's reaction for desoxyribose is the best example. There exists also a reaction for both desoxyribose and ribose of nucleic acids described by Turchini, Castel, and Kien (1944), employing phenyl (or methyl) trihydroxy fluorone after acid hydrolysis. This method is not much employed for animal tissues. Variations of the coupled tetrazonium reaction have been used to produce Plate I, Fig. 2, and Figs. $12,13,14$, and 17. These sections illustrate the scope of the method and some of the problems it may help to answer. They show that many other structures, besides those containing nucleic acids, are 
resistant to the effect of benzoylation and acetylation, especially if mild heat has previously been applied to the sections. Collagen and reticulin (Fig. 15), for instance, are invariably resistant. In Plate I, Fig. 1, the mucin of the brush

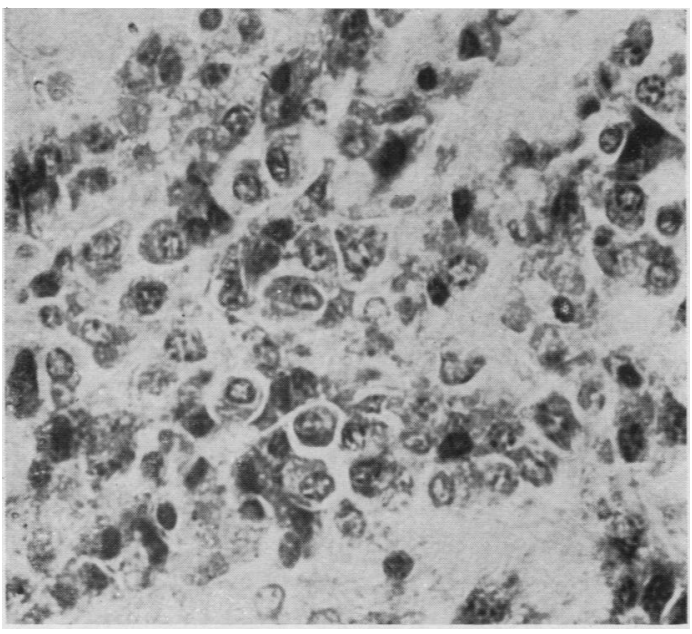

FIG. 19.-A group of plasma cells with granular basophilic cytoplasm containing a large amount of ribonucleic acid. Pyronin-methyl green $\times 520$. border of the villus stains brilliantly with the periodic-acid-Schiff (P.A.S.) method. Plate I, Fig. 2, shows that it fails to stain by the tetrazonium method after benzoylation. This is probably due to its depolymerization by enzymes in the lumen of the intestine. Fig. 16 shows that the A bands of striated muscle stain strongly by the P.A.S. method, especially in frozen sections. This is only partly due to glycogen. Fig. 17 shows that the $\mathrm{A}$ bands stain by the tetrazonium method after benzoylation, as they do after acetylation, whereas the beta granules of the pituitary gland (Fig. 18) withstand benzoylation only (Pearse, 1950b). What cannot be decided on the present evidence is whether these reactions are in each case due to the physical state of the component proteins or whether they are due to the presence of other substances such as adenosine triphosphate (in the A bands) or ribonucleic acid (in the beta granules).

During the past few years a number of extraction techniques for nucleic acids, derived from chemical procedures in the first instance, have been applied to histochemistry.

Sodium Chloride Solutions.Mirsky and Pollister (1946), for instance, found that ribonucleoprotein and desoxyribonucleoprotein could be extracted from liver by $0.85 \%$ and molar $\mathrm{NaCl}$ respectively. This action is due to the depolymerization of nucleohistones by salt solutions, especially in molar concentration. White (1950), using bone-marrow smears, has shown that these actions can be demonstrated cytologically by staining in aniline blue-orange $\mathrm{G}$ mixtures at $p \mathrm{H} 2$ to 3.

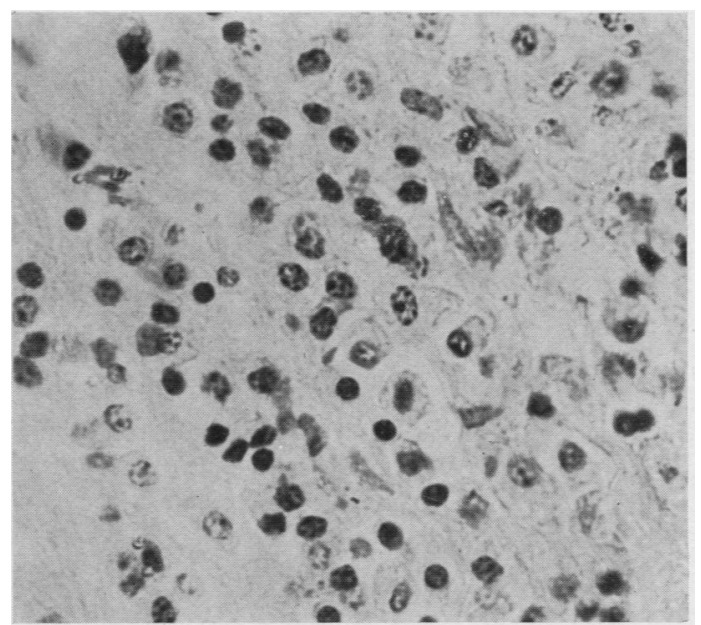

FIG. 20.-A group of plasma cells in a section treated with $10 \%$ perchloric acid at $4^{\circ} \mathrm{C}$. for 16 hours. Ribonucleic acid has completely disappeared. The nuclei, green after ribonuclease, are red by this method. Pyronin-methyl green $\times 520$. 
Perchloric Acid.-After initial work by Ogur and Rosen (1949), Erickson, Sax, and Ogur (1949) evolved a method for the extraction of ribonucleic acid from alcoholfixed sections, using cold $10 \%$ perchloric acid for between four and 18 hours. They also extracted both nucleic acids by treatment with the same reagent at $70^{\circ} \mathrm{C}$. for 20 minutes or less. The effect of the perchloric acid hydrolysis was estimated by staining control and treated sections with $1 \%$ aqueous toluidine blue. Seshachar and Flick (1949) employed this method to extract ribonucleic acid from protozoan cells, and Sulkin and Kuntz (1950) used it on Zenkerfixed mammalian tissues followed by . Mallory's phloxin-methylene blue stain. Erickson and his coworkers and Sulkin and Kuntz both considered that perchloric acid could be substituted for ribonuclease

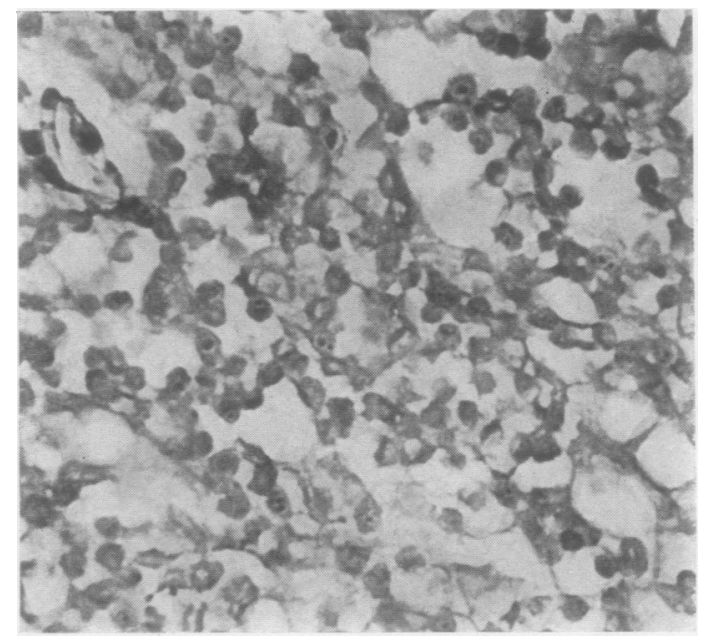

Fig. 21.-A group of plasma cells showing the small affinity of the nuclei for acid dyes. Light green S.F. $\times 520$. in the histochemical detection of ribonucleic acid. The former authors obtained comparable, and the latter identical, results using ribonuclease on the one hand and cold perchloric acid on the other. This has not been my experience and I consider that their views are premature. Ribonuclease, freed from proteolytic activity, removes ribonucleic acid and nothing else from sections. Cold perchloric acid

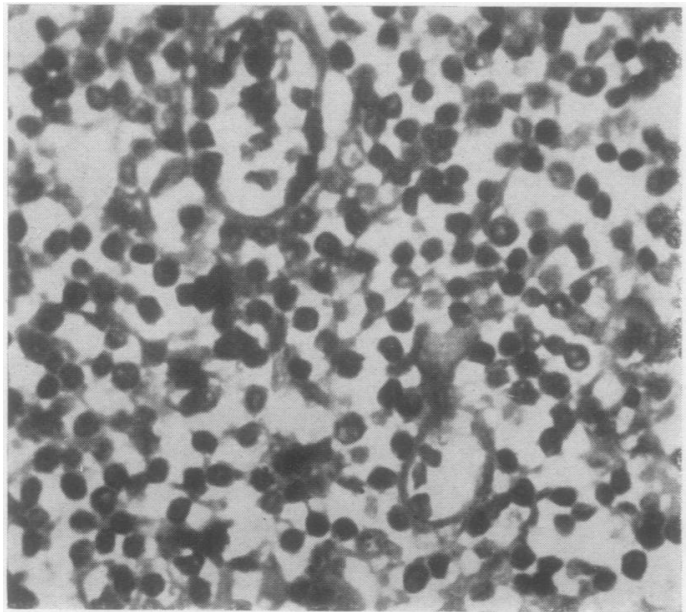

FIG. 22.-Serial section to Fig. 21 treated with $5 \%$ trichloroacetic acid at $90^{\circ}$ C. for 15 minutes (Schneider extraction). Stained and photographed as Fig. 21. Light green S.F. $\times 520$. extraction certainly removes all ribonucleic acid, but also extracts various protein, glycoprotein, and lipoprotein materials. When the optimum times of perchloric acid hydrolysis for tissues fixed in various fixatives are known, as they are for the acid hydrolysis of the Feulgen reaction, for instance, the method will be of considerable value to histologists. In this country, at all events, it should supersede the use of the not easily obtainable ribonuclease. Figs. 19 and 20 illustrate the results of 16 hours' treatment with $10 \%$ perchloric acid at $4^{\circ} \mathrm{C}$. on a group of plasma cells. Both control and treated sections are stained by the Unna-Pappenheim method. 
Bile Salts.-Henry and Stacey (1943), in their experiments on the nature of the Gram-positive complex in micro-organisms, employed solutions of bile salts $(2 \%$ aqueous sodium cholate) at $60^{\circ} \mathrm{C}$. in the presence of oxygen for the removal of ribonucleic acids from bacterial cells. This method has been applied by Foster and Wilson (1951) to the extraction of ribonucleic acid from the anterior pituitary beta granules.

Trichloroacetic Acid.-Schneider (1945) used $5 \%$ trichloroacetic acid, at $90^{\circ} \mathrm{C}$. for 15 minutes, to extract nucleic acids from the tissues. Both desoxy and ribonucleic acids are extracted by this procedure, which has been applied by White (1950) to bone-marrow smears and by Kaufmann, Gay, and McDonald (1950) to onion root tips. Schneider extraction increases the stainability of the nuclei with acid dyes. Figs. 21 and 22 illustrate its application to Helly-fixed tissues followed by staining with light green S.F.

Other Acids.-Other acids, such as hydrochloric, have been employed for nucleoprotein extraction (Sevag, Smolens, and Lackman, 1940; Davidson and Waymouth, 1944), while Caspersson, Hammarsten, and Hammarsten (1935) employed malonic acid for the purpose. Normal $\mathrm{HCl}$ at $37^{\circ} \mathrm{C}$. for three hours has been employed by Dempsey, Singer, and Wislocki (1950) as a means of reversing the tissue basophilia due to nucleoproteins. Finally, it must not be forgotten that Brachet (1940) showed that ribonucleic acid was removed by incubation in water at $60^{\circ} \mathrm{C}$. When an accurate assessment of the optimum time of exposure is available, the perchloric acid method is likely to be the most useful of all the methods in this section to histologists.

\section{Methods for Glycogen and Ascorbic Acid}

Recent conceptions of the chemical and physical structure of glycogen have indicated that there are a number of naturally occurring glycogens with different degrees of polymerization and hence with different solubilities (Meyer, 1943). This knowledge has partly explained the difficulties in histological fixation of glycogen, but has made no difference to the demonstration of glycogen in tissue sections. There are still five methods in use for this purpose and each has its adherents. The staining of glycogen with watery solutions of iodine, though certainly the oldest method, is still employed in modern histochemistry (Mancini, 1944) and has its use, especially for freeze-dried material. The original Bauer-Feulgen method described by $\mathbf{H}$. Bauer (1933) employs hydrolysis of the polysaccharide with $4 \%$ chromic acid for a short period followed by demonstration of the resulting polyaldehyde with Schiff's solution. It is less often employed in modern histochemistry than the other methods though strongly recommended by C. M. Bensley (1939), and employed by Bunting and White (1950) in their studies on scurvy. Several methods have been devised which employ hydrolysis followed by solutions of silver (Mitchell and Wislocki, 1944; Gomori, 1946c; Arzac, 1947; Arzac and Flores, 1949). Mitchell and Wislocki and Arzac used potassium permanganate as the hydrolysing agent followed by ammoniacal silver solutions, while Gomori employed $10 \%$ chromic acid and a hexamine-silver complex for visualizing the aldehyde groups revealed by the hydrolysis. All these methods are similar in effect to Bauer's original method, but reveal mucins and reticulin in addition. Gomori's is probably the best of the three. The periodic-acidSchiff reaction (McManus, 1946b; Lillie, 1947; Hotchkiss, 1948) reveals glycogen 
particularly clearly and has been used for this purpose by Marchese (1947), Wislocki, Rheingold, and Dempsey (1949), Gibb and Stowell (1949), and by McManus and Findley (1949), among others. Lastly, empirical as it is, the ammoniacal carmine solution of Best (1906) cannot be dismissed. It remains in current use by histochemists as well as by histologists (Lison and Vokaer, 1949).

Whichever method is used for demonstrating glycogen in the tissues, control sections incubated with saliva, or with suspensions of malt diastase or ptyalin (Lillie and Greco, 1947), must always be employed if there is any doubt as to the nature of the substance under review. Although the work of Willstätter and Rohdenwald (1934) suggested that glycogen might be bound to protein as desmoglycogen there is no evidence that bound glycogen occurs in any form which resists the action of ptyalin or diastase. That which does so, by whatever method it be revealed, is not glycogen. All the methods in current use for glycogen stain other materials as well, with the exception of Best's stain, properly differentiated. I therefore consider that improved fixation, such as that recommended by Lison, followed by Best's stain and accompanied by diastase-treated control sections, is the most suitable combination for accurate study of the glycogens.

The acid silver technique of Bourne $(1933,1936)$ for ascorbic acid is mentioned here, as the amount of this substance present in the adrenal gland is often used as a criterion of adrenal function. Barnett, Bourne, and Fisher (1941) modified the reaction to increase its specificity, but the latter is not yet established (K. F. Bauer, 1943; Danielli, 1946). The reaction has been used, particularly on the adrenal gland, by Giroud and Leblond (1936) and by Greep and Deane (1949).

\section{Methods for Mucopolysaccharides, Muco and Glycoproteins}

The whole of the modern histochemistry of these substances is bound up with the periodic-acid-Schiff (P.A.S.) reaction of McManus (1946b) and Hotchkiss (1948), which the former author originally described for the staining of mucin. For this purpose, histologically as well as histochemically, it has no peer (Plate I, Fig. 1). It possesses the great advantage of staining neutral as intensely as acid mucopolysaccharides so that gastric mucin, which contains a large amount of the former, stains as strongly as intestinal mucin. The P.A.S. reaction, preferably employing the alcoholic solutions and reducing rinse advocated by Hotchkiss, develops a magenta colour with 1.2 glycols or amino-glycols, which are oxidized to dialdehydes by the periodic acid. Carbonyl groups are oxidized to carboxylic groups and do not, therefore, give a positive reaction. Theoretically, a large number of substances which contain the 1.2 glycol group should give a positive reaction. In practice, if the P.A.S. method is used on paraffin sections after aqueous fixatives, five groups of substances give positive results, and these are not visible in control sections unexposed to periodic acid. They are (1) polysaccharides (glycogen), (2) mucopolysaccharides (mucins, hyaluronic acid, heparin), (3) muco and glycoproteins (mucoids, gonadotrophic, and thyrotrophic hormones, fractions of serum albumin and globulin), (4) glycolipids (kerasin, phrenosin), and (5) phospholipids (lecithin, cephalin, inositol phosphatide, etc.). The presence of reactive substances in the two lipoid groups is determined by staining control frozen and paraffin sections by various methods and, if these suggest that the positive P.A.S. reaction is due to lipoid, by performing the reaction on sections from control blocks fixed in boiling chloroform-methanol for eight to 16 


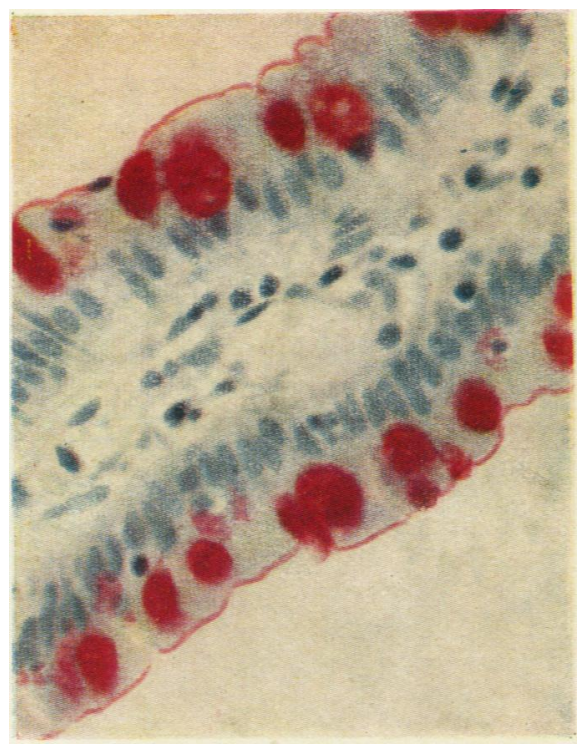

FIG. 1.-Human duodenal villus. Strongly P.A.S.-positive mucin granules are seen in the goblet cells, and less positive mucin in the brush border. Periodicacid-Schiff, celestin blue-haemalum $X$ 440.

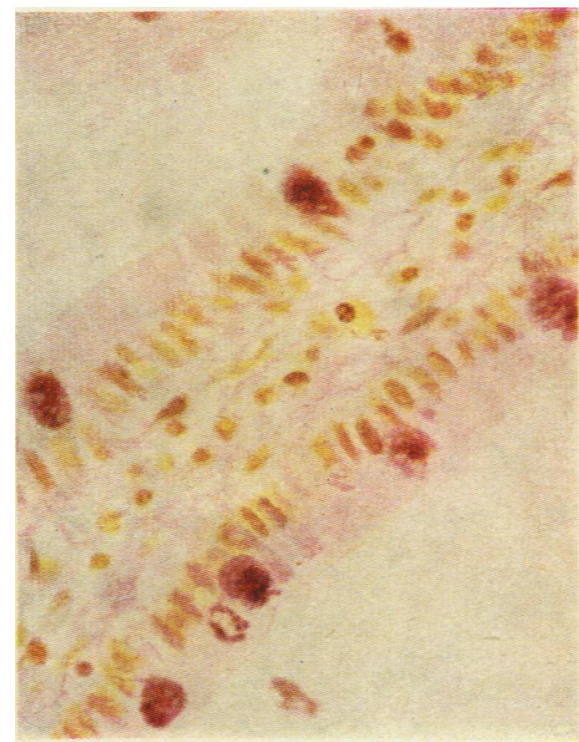

FIg. 2.-A similar villus for comparison with Fig. 1. The granular mucin in the goblet cells stains positively, but the brush border is unstained. Sixteen hours' benzoylation at $22^{\circ} \mathrm{C}$. Coupled tetrazonium reaction $\times 440$.

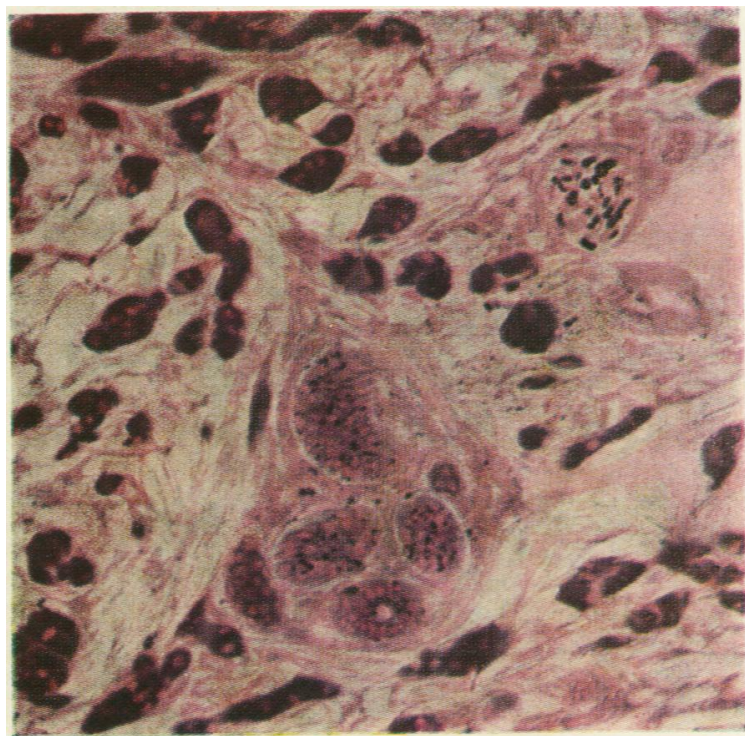

FIg. 3.-Human skin (10 $\mu$ frozen section) infiltrated by cells of so-called granular myoblastoma. Sudan black stains the myelin sheaths, fat globules in the sweat glands, and the specific granules of the tumour cells. Sudan black B, carmalum $\times 150$. 


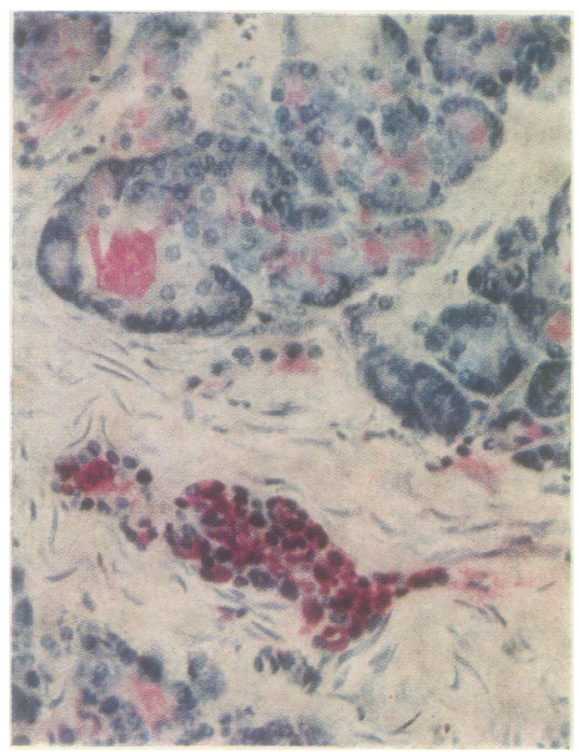

Fig. 4

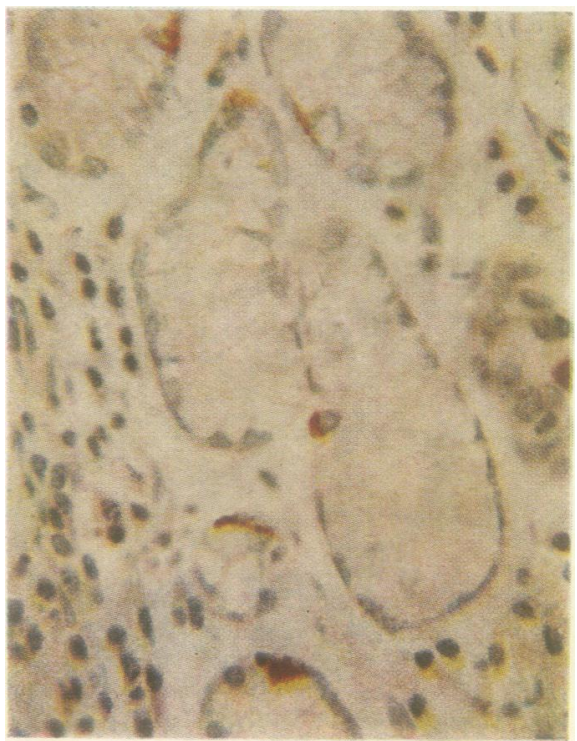

Fig. 5

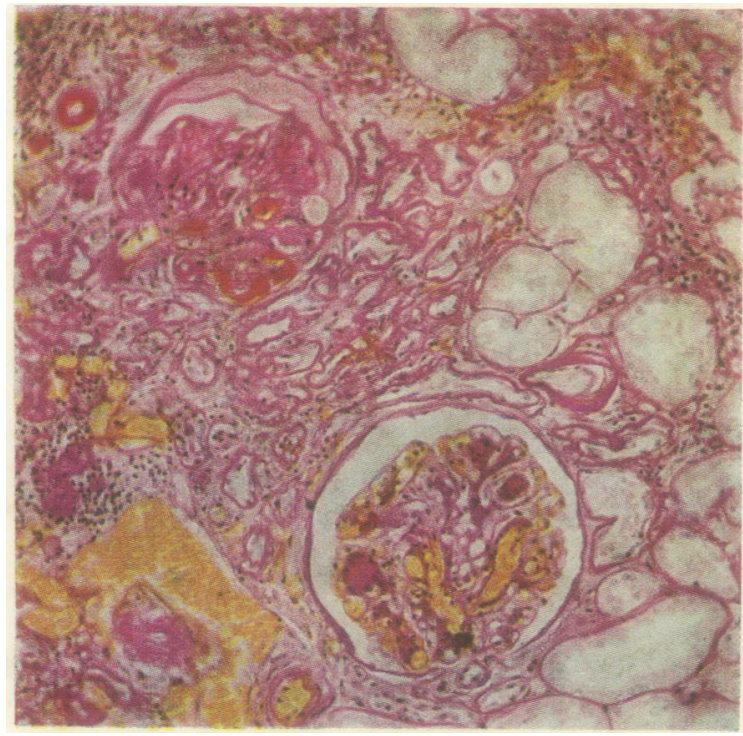

FIG. 6
FIG. 4.-Human pancreas (10 $\Perp$ freeze-dried section) showing, below, mucopolysaccharide in a duct and, above, mucoprotein secretion in the acini. Periodic-acid-Schiff, toluidine blue $\times 525$.

FIG. 5.-Human stomach. Pyloric glands showing orange-red granules in the argentaffin cells. Diazotized dinitroanisidine (Echtrotsalz B). Iron haematoxylin $\times 600$.

FIG. 6.-Human kidney. Kimmelstiel-Wilson syndrome. Note the hyaline change in afferent arteriole and intraglomerular capillaries. (Section overstained to provide colour contrast.) Periodic-acid-Schiff. Celestin blue-haemalum. Phosphotungstic acid-orange $\mathbf{G} \times 97$. 
hours. This last procedure will remove all lipoid (with the possible exception of some lipoprotein complexes), and a positive P.A.S. reaction after such a manœuvre is due to substances in the first three groups. Separation of these three groups can also be achieved (see below), making the P.A.S. reaction a useful one in many fields of histochemistry.

Additional methods for the distinction of acid mucopolysaccharides are of three types : (a) methods depending on the production of metachromasia, $(b)$ methods depending on the degree of basophilia, $(c)$ the dialysed iron method (Hale, 1946).

The work of Michaelis and Granick (1945) has introduced the conception that polymer formation is responsible for the development of metachromasia with the thiazine dyes (thionin, toluidine blue, methylene blue). Many dyes in other groups stain metachromatically, pyronin in mast cells, for instance, and celestin blue with mucins (Lendrum, 1947). Lison (1935a) gives a full list. Histochemically, metachromasia can be defined as the staining of a tissue component so that the absorption spectrum of the resulting tissue-dye complex differs sufficiently from that of the original dye and from its ordinary tissue complexes to give a marked contrast in colour. For practical purposes metachromasia refers to the use of dyes of the thiazine group. Polymerization of the substrate, with which the thiazine dye combines, induces polymerization of the dye, and hence metachromasia. New light is thus thrown on the induction of metachromasia which Lison (1936) believed to be a specific histochemical test for higher esters of sulphuric acid (acid mucopolysaccharides), although Feyrter (1936) in the same year had shown that myelin sheaths were strongly metachromatic in frozen sections. Sylvén $(1941,1945)$ maintained that only such metachromasia as could withstand the process of dehydration with alcohol was the "true" metachromasia due to ester sulphates. One cannot wholly agree with Sylvén's definitions, because alcoholic dehydration is capable of removing all metachromasia if used for long enough, and the amount of his "true" metachromasia in any given section depends on individual technique. Following Michaelis (1947), it is possible to recognize two varieties of metachromasia in histochemistry. This author has shown that toluidine blue has an absorption spectrum with three bands, alpha, beta, and gamma. The monomeric alpha form is blue, the dimeric beta form violet, and the polymeric gamma form is red. Certainly gamma (red), alcohol-resistant metachromasia in paraffin sections is most likely to be due to sulphate esters. Less alcohol-resistant gamma metachromasia, and beta (violet) metachromasia, can be caused by highly polymerized carbohydrate or phosphate-containing compounds. Despite Michaelis's results in vitro, nucleic acids occasionally give beta metachromasia in paraffin sections. This feature has been recorded by Wislocki, Bunting, and Dempsey (1947), and I have often observed it. Hempelmann's (1940) claim that distinction between chondroitin and mucoitin sulphuric acids can be made by staining with exceedingly dilute solutions of toluidine blue (which are supposed to stain only the former compounds) cannot be substantiated. Friedenwald (1947) observed that the distinction between meta and orthochromatic staining of tissues could be exaggerated by staining in the presence of high concentrations of magnesium chloride. At $p \mathrm{H} 1.5$ nucleic acids fail to stain if the solution is saturated with magnesium chloride, whereas cartilage and mast cells still do so. This technique is a valuable one. The method of Hess and 
Hollander (1947) for permanent metachromatic staining of mucin is useful histologically rather than histochemically.

It has long been customary to diagnose the presence of acid mucopolysaccharides by means of their basophilia. More recently, using the method originated by Pischinger (1926, 1927), Dempsey and Singer (1946), Dempsey, Bunting, Singer, and Wislocki (1947), and Dempsey, Singer, and Wislocki (1950) have used a technique for making qualitative estimation of the degree of basophilia registered by tissue compounds. This involves staining with $\mathrm{M} / 2,000$ methylene blue at various $p H$ levels for 24 hours, mounting sections with minimum dehydration, and applying spectrophotometric measurement to the amount of dye bound by the various tissue components. I have employed this method, without spectrophotometry, using as endpoint the virtual extinction of binding capacity for methylene blue (Pearse, 1949, 1950a). The methylene blue extinction method makes possible a comparative estimation of the degree of basophilia manifested by various structures and is particularly useful for distinguishing between acid mucopolysaccharides and mucoproteins.

Hale's (1946) method depends on the combination of dialysed iron, in acid solution, with the sulphate groups of acid mucopolysaccharides or with the uronic acid groups of hyaluronic acid where this occurs in its non-sulphated form. Hale maintains that hyaluronic acid, suitably preserved by alcoholic fixation, is specifically demonstrated by the reaction and that the dialysed iron does not combine with neutral mucopolysaccharides or with proteins. After washing, iron combined in the tissues is visualized by the Prussian-blue reaction. Though the method has apparently been used successfully by Hudack, Blunt, Higbee, and Kearin (1949) and by Ritter and Oleson (1950), who combine it with a peroxidase stain and with the P.A.S. reaction, I have not found that the affinity of fixed tissues for iron is limited to the acid mucopolysaccharides. Hale's reaction is, therefore, not specific, and it is far less easily controlled than methods depending on metachromasia or basophilia. Lillie and Mowry (1949) have investigated the absorption of iron by tissue sections, using $\mathrm{M} / 100$ ferric chloride in $1 \%$ mannitol, and have shown that mucin, reticulin, and collagen are selectively impregnated.

In modern methods of enzymal analysis at least ten enzymes besides the classical trypsin and pepsin are, or have been, employed. Only three are likely to be required for ordinary use in pathology. These are diastase and ribonuclease, already referred to, and hyaluronidase, recommended by Hale (1946) for the positive identification of hyaluronic acid. There are three common sources of hyaluronidase: (1) streptococcal culture filtrates; (2) clostridial culture filtrates; (3) mammalian testis extracts. Hyaluronidase from all three sources has been used in histochemistry by various workers, but the last source is the most convenient and this hyaluronidase is now obtainable in dried form as a commercial preparation. Such dried testis extracts can be used at about $0.1 \%$, in $0.3 \%$ sodium chloride (Bunting and White, 1950) or in $0.1 \mathrm{M}$-phosphate buffer (Gersh, 1949b), at between $p \mathrm{H} 6.0$ and 7.0 and for 12-24 hours at $37^{\circ} \mathrm{C}$. Metachromatic material present before and absent after incubation with hyaluronidase is not necessarily hyaluronic acid. Meyer (1947) has shown that testis hyaluronidase can also depolymerize the chondroitin sulphate of cartilage. Control sections, incubated preferably with boiled enzyme solution, must always be employed. Although formalin-fixed material has often been used, alcoholic fixation is preferable. 


\section{Methods for Lipoids, Lipoproteins, and Sterols}

There are few methods in modern histochemistry primarily designed for the demonstration of lipoids or lipoproteins. Of the older methods a number have fallen into disuse and others continue to be employed although their significance is dubious. For neutral fats the most widely used techniques all depend on the solubility of the inert dis-azo dyes in the fats themselves, and for this purpose Sudan III and Sudan IV are most commonly employed. Kay and Whitehead (1934) found that Sudan III was unsatisfactory as a fat stain and later (1935) proposed and used Sudan IV for this purpose. These same authors (1941) tested a large number of Sudan dyes and concluded that impurities played a part in strengthening the colour imparted to fat in tissue sections. They showed that in mixtures of the Sudan dyes each dissolves independently of the other and the total amount of dye available for staining depends on the number of Sudans present. It is therefore good practice, in a routine fat stain, to use a saturated mixture of Sudan III and Sudan IV in $70 \%$ alcohol or in Herxheimer's solution in place of Sudan IV alone. The greatest advance in fat-soluble dye technique has come from the use of Sudan black B, first introduced by Lison (1936) and employed, among other things, for staining the granules in neutrophil leucocytes by Sheehan (1939), McManus (1945), Wislocki and Dempsey (1946), and Eränkö (1950). Sudan black is usually employed as a saturated solution in $70 \%$ alcohol, despite the objections of Leach (1938), who recommended $50 \%$ diacetin as solvent. This dye has the advantage of being soluble in phospholipids and to some extent in cerebrosides; it can therefore be used for staining them in tissue sections if they are preserved by suitable fixation (Plate I, Fig. 3). McManus (1946a) used a formalin, calcium, cobalt mixture, substituting cobalt for the cadmium of Baker's (1944) fixative for phospholipins. He post-chromed his material when necessary and pointed out that Sudan black might be used on paraffin sections if suitable fixatives were employed. Since formalin alone fixes lipoids to some extent it is always worth while applying the Sudan black technique to formolfixed paraffin sections when nothing else is available; though a negative result is of no importance, positive results signify formol-fixed lipoid which is usually phosphatide or cerebroside. Other methods in modern use for phosphatides include the Smith-Dietrich method (dichromate-haematoxylin), used by Baud (1948) in a study of perinuclear lipoid layers, the Feyrter (1936) reaction (tartaric acid-thionin on frozen sections) for chromotrope substance, used by Pischinger (1943) and by Pretl (1948), and the acid haematein and pyridine extraction methods described by Baker (1946). Alsterberg (1941) described a new method, said to be specific for phosphatides, involving treatment of unfixed material with "iodine-cyanide" followed by silver chlorate impregnation. At the time of writing I have no experience of this method. Osmic acid is not now employed in histochemistry, and LorrainSmith's Nile-blue sulphate, though used as recently as 1950 by Gerebtzoff, Dallemagne, and Philippot, is infrequently employed. Lison (1935a and b) considered that a blue colour with Nile blue was quite unspecific for fatty acids though a red colour signified unsaturated glycerides. More recently Cain (1947), using a new technique, has shown that Nile blue can be used to distinguish neutral lipoids (esters and hydrocarbons) from acidic lipoids (phospholipids).

It has already been stated that the periodic-acid-Schiff reaction is positive with some lipoid materials, notably the cerebrosides and phosphatides. Morrison and 
Hack (1950) obtained a brilliant colour in formol-fixed paraffin sections of material from Gaucher's disease stained by this reaction. I found a much less striking development of colour in a single case investigated, but this may have been due to extraction of kerasin by prolonged immersion in formalin. Hack (1949) has found that phosphatides react with P.A.S. in vitro; this presumably occurs by virtue of their alpha-amino-alcohol radicles. The P.A.S. method, therefore, can be used in the investigation of formol-fixed lipoid. Preliminary studies indicate that if oxidation is carried out with performic instead of periodic acid, followed by treatment with Schiff's solution (P.F.A.S.), a component which is present in keratin and in the red-cell envelope gives a positive result before any other structures react.

Carleton (1926) and others pointed out that many intracellular lipoidal components were masked. Ciaccio's method of acetone-extraction, and subsequent demonstration by fat-soluble dyes, aimed at revealing these masked lipoids; modern extraction techniques, however, are used for removing rather than revealing. Baker (1946) used pyridine extraction to provide control sections for his method by removing the phospholipid, leaving only certain protein substances to react. Keilig (1944), working on unfixed blocks of human brain, used cold and hot acetone, hot ether, and hot chloroform-methanol to separate the various classes of lipoids. He attached a definite significance to each step, unlike subsequent workers such as Baker and Kent (1950), who used petroleum ether, acetone, alcohol, benzene, and chloroform. As Morrison and Hack found with kerasin, extraction techniques usually fail after formalin fixation and the results are impossible to interpret. Acid haematin and Sudan black are the methods of choice for staining lipoid material other than neutral fat, in conjunction with Keilig types of extraction technique. If Sudan black is used, extraction must not be followed by any fixative or mordant process. Biochemists have not yet decided whether lipoproteins consist of stoichiometrical compounds or of fat micelles covered with protein, or of protein molecules surrounded by layers of lipoid. Whichever they are, they are sometimes resistant to the action of extractives but not usually to hot chloroform-methanol, which removes all lipoids. In tissue structures which contain both protein and formol-fixed lipoid, the two substances are likely to be present in the form of a complex, the lipoid fraction being removable by one or other of Keilig's solvents.

Cholesterol and Ketosteroids.-The following reactions are employed: sudanophilia; (2) birefringence; (3) autofluorescence; (4) Liebermann-Burchardt reaction; (5) Schiff reaction; (6) phenyl- and 2-4 dinitrophenylhydrazine reactions; (7) ammoniacal silver reactions (Reichstein and Shoppee, 1943); (8) hydroxynaphthoic acid hydrazide reactions. All these are subjected to control by using parallel sections treated with cold acetone which removes cholesterol and ketosteroids. Sudanophilia, which has already been discussed, and the silver reactions, which have no advantages for the demonstration of carbonyl groups in the tissues, are not further considered here. The Liebermann-Burchardt reaction, using concentrated sulphuric and acetic acids, produces coloured compounds with unsaturated steroids and is now known to be a general steroid reaction and not specific for cholesterol (Bierry and Gouzon, 1936). It has been used by Dempsey and Bassett (1943) on the ovary, by Everett (1945), and by Greep and Deane (1949) on the adrenal cortex. Both cholesterol and the ketosteroids show birefringence of the 
type shown in Fig. 23 (actually a photograph of myelin sheaths by polarized light), and Bennett (1940) increased this birefringence of adrenal cortical lipoids by a modification of the digitonin reaction of Leulier and Revol (1930). Digitonin forms insoluble anisotropic esters with steroids. Steroid compounds also exhibit autofluorescence in ultra-violet light, as shown by Hamperl (1934), Vlès and Ugo (1936), Wadsworth and Crowe (1936), and Deane and Greep (1946). Reactions particularly used for the demonstration of ketosteroids are the stwo phenylhydrazine reactions, the Schiff

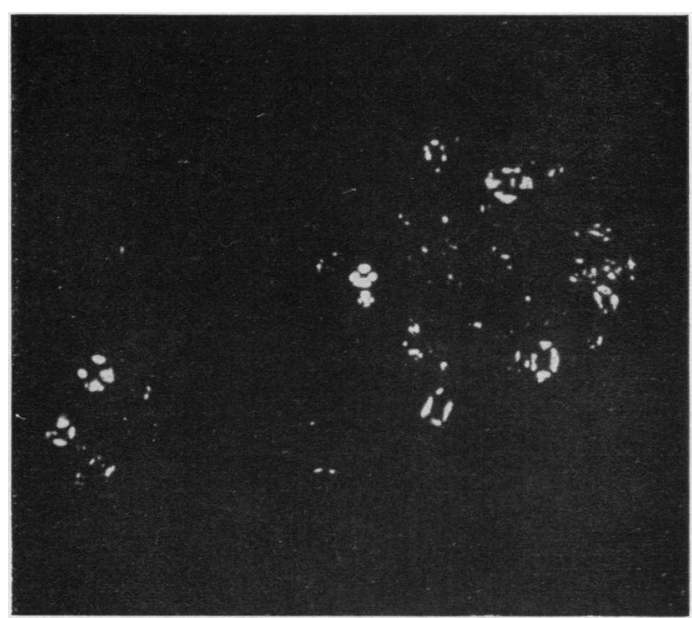

FIG. 23.-Myelin sheaths photographed by polarized light to show maltese-cross birefringence. $\times 350$.

reaction, and the naphthoic acid hydrazide reaction. The phenyl hydrazine reaction was employed by Bennett $(1939,1940)$ and subsequently by Popják (1944) and others. while Dempsey and Wislocki (1946) and later Albert and Leblond (1946) tried to improve the yellow colour of the steroid-phenylhydrazone by using 2-4 dinitrophenylhydrazine. The test with Schiff's reagent is really the plasmal reaction of Feulgen and Voit (1924) which is given especially by the higher fatty aldehydes (acetal phospholipids, plasmalogens). Its application to the adrenal gland in different animal species was reported by Voss (1940). Finally, Camber (1949) and Ashbel and Seligman (1949) independently produced a reaction depending on the formation of coloured hydrazones by combining an arylhydrazide with the tissue steroid and coupling the resulting compound to a diazonium or tetrazonium salt. Using 2-hydroxy 3-naphthoic acid hydrazide and coupling with diazotized dianisidine, the final product has an easily visible bluish-purple colour and is soluble in cold acetone. Fig. 14 illustrates the application of this method to the human adrenal (nuclei unstained; chrome glycerin jelly mountant).

All the methods given above for ketosteroids are non-specific and have been extensively criticized as such. Gomori (1942) considered that the phenylhydrazine reaction signified the presence of plasmalogens in large amounts, and Albert and Leblond (1946) also considered that the phenylhydrazine reaction was equivalent to the plasmal reaction. Boscott and Mandl (1949) stated that all the ketosteroid reactions (they did not review the Ashbel-Seligman method) were non-specific and would be given by an artificial mixture of various lipoid constituents of the tissues. These authors performed amine-aldehyde condensations (Oster and Mulinos, 1944) on sections of human and rat adrenals, and found thereafter that not only was the Schiff reaction for aldehydes negative as expected, but also the dinitrophenylhydrazine reaction. Ketones, therefore, were not present. Aldehydes as well as ketones react by the Ashbel-Seligman method, which can be used in the Feulgen reaction for nucleic acid (Fig. 12) or after periodic acid in place of Schiff's reagent. The specificity of this method, therefore, depends on whether tissue aldehydes react 
under the conditions of the experiment. Blocking techniques using semicarbazide (Bennett, 1940) are of no assistance, as they block both aldehydes and ketones from subsequent reaction with hydrazides. Ashbel and Seligman consider that aldehydes do not react by their method, but proof is lacking. I have found that the Schiff and Ashbel-Seligman reactions do not give exactly parallel results on human or rat adrenals, but there is a good deal of overlap between the two, and I consider that the specificity of the latter reaction for ketosteroids remains open to question.

\section{Methods for Alkaline and Acid Phosphatases}

Alkaline Phosphatases.-It is quite impossible in a short review to cover all the work on alkaline phosphatase following the original method which was conceived, independently, by Gomori (1939) and by Takamatsu (1939). In the past five years the number of papers referring to the alkaline phosphatases in histochemistry considerably exceeds that of any other single method. This is evidence, at the outset, that the method is reliable and easy, and that it produces a visible and stable result. Too many histochemical techniques proposed in the immediate past have failed to satisfy these criteria. It is necessary, however, to add the warning given by Danielli (1950b) that the Gomori technique is deceptively simple from the point of view of the interpretation of results. Some of the arguments which follow should make this clear. I propose to refer shortly to various papers dealing with the method itself, following this by a short résumé of the points on which its specificity is criticized and by reference to some recent works of general interest to histologists.

Besides the classical method of Gomori, methods using other principles have been evolved; these are briefly reviewed below. Menten, Junge, and Green (1944) produced a histochemical azo dye test, depending on the hydrolysis of calcium beta naphthyl phosphate and the instant reaction in situ of the free beta naphthol with diazotized alpha naphthylamine at $p \mathrm{H} 9.4$ to give a red colour in sites of alkaline phosphatase activity. Danielli (1946) used phenyl phosphate as well as beta-naphthyl phosphates, coupled with diazotized beta naphthylamine, to accomplish a similar reaction. He also used phenolphthalein phosphate, demonstrating the hydrolysed phenophthalein by exposing the sections to the fumes of ammonia. Manheimer and Seligman (1949) modified the technique of Menten et al. by the use of a stable diazotate in place of freshly diazotized alpha naphthylamine. These techniques have proved useful as controls for the specificity of the Gomori method but not for ordinary use. A variation of the original technique (Gomori, 1946a) is commonly used at the present time. It depends on the deposition of calcium phosphate at sites of enzyme activity when sections are incubated with an organic phosphate ester in the presence of calcium

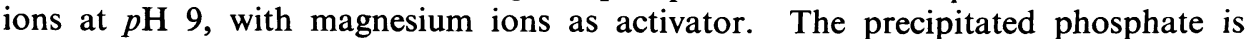
visualized by conversion to the cobalt salt and finally to black cobalt sulphide. Alternatively (Kabat and Furth, 1941) von Kóssa's silver method for calcium may be used. Newman, Feigin, Wolf, and Kabat (1950) give good reasons for objecting to the use of cobalt.

In order that a calcium deposit may take place in the tissues the rate of production of phosphate ions must be high enough for the solubility product of calcium phosphate to be exceeded locally. The establishment of this condition is prevented by many factors: (1) inactivation of the enzyme during fixation and embedding (Emmel, 1946; Danielli, 1946; Stafford and Atkinson, 1948), during the process of mounting 
on the slide (Ruyter and Neumann, 1949), and possibly during storage (Lison, 1948); (2) departure from optimum $p \mathrm{H}$ values (lowering the $p \mathrm{H}$ below 9.0 interferes by slowing the action of alkaline phosphatase and by increasing the solubility of calcium phosphate); (3) the presence or absence of enzyme activation; (4) the use of unsuitable substrates which are too slowly hydrolysed; the interpretation of results (Gomori, 1950a) is made difficult by (5) false negative reactions due to inactivation or subthreshold amounts of enzyme; (6) false positive reactions due to other black pigments or to preformed calcium; (7) false localization, due to diffusion of the enzyme during and after fixation (Lison, 1948), or by diffusion of the products of hydrolysis (Jacoby and Martin, 1949; Feigin, Wolf, and Kabat, 1950; Gomori, 1950b). Quantitative estimation is possible according to Gomori $(1950 \mathrm{~b})$ only by means of laborious comparative experiments. Danielli (1950b), on the other hand, suggests that incubation for a logarithmic series of times gives quantitative appreciation, sites of highest activity appearing before the other sites. It seems that the shorter the incubation can be kept, the more accurate is localization likely to be. In particular the localization of alkaline phosphatase in the nuclei is criticized as being an artifact due to diffusion. Newman, Feigin, Wolf, and Kabat (1950) divided alkaline phosphatases into three groups, one of which is a distinct nuclear phosphatase. Feigin et al. (1950) showed that the increased nuclear staining, which occurs adjacent to a locus of intense activity, was due to phosphatase characteristic of that locus and not to the nuclear enzyme. Fig. 8 shows a section of freeze-dried rabbit kidney incubated for three hours with $M_{2} 200$ phenyl phosphate and visualized by the method of von Kóssa. In this short incubation the nuclei were completely unstained and they were counterstained with carmalum for photographic purposes.

Much argument also ranges about the point whether there are a number of different alkaline phosphatases or only one. Evidence derived from in vitro studies of resistance to inhibitors and optimum $p \mathrm{H}$ suggests that a number of phosphatases exist (Belfanti, Contardi, and Ercoli, 1935; Bodansky, 1937; Gould, 1944). Other investigators (Glick, 1946; Dempsey and Deane, 1946; Deane, 1947; Dempsey and Wislocki, 1947; Dempsey, 1949; Friedenwald and Maengwyn-Davies, 1950) believe that various alkaline phosphatases can be distinguished histochemically. Gomori $(1950$ c) demurs. Reis $(1937,1940,1950)$ considers that there is a specific 5-nucleotidase acting on adenylic acid at $p \mathrm{H} 7.5$ to 8.0, and Gomori (1949a), using adenylic acid at $p \mathrm{H}$ 9.0, demonstrated this histochemically. Pearse and Reis (unpublished) have also demonstrated 5-nucleotidase histochemically, using adenylic acid at $p \mathrm{H}$ 7.5. Figs. 24 and 25 illustrate the difference between alkaline phosphatase and 5-nucleotidase in the rat adrenal gland, incubated with either substrate for three hours at $37^{\circ} \mathrm{C}$. Such a difference might prove useful for differentiating between cortical and medullary tumours of the adrenal.

The distribution of alkaline phosphatase in normal tissues was described by Gomori (1941a) and by Bourne (1943), and in normal and neoplastic tissues by Kabat and Furth (1941). The kidney has been investigated, especially by Bunting (1948), Soulairac, Desclaux, and Teysseyre (1949a and b), and by McManus and Mowry (1948). The last is a valuable paper dealing with the application of the method to pathological human material. Abolins (1948) and Abolins and Abolins (1949) have investigated the pituitary gland and Fisher and Glick (1947) the skin. Follis (1949) deals with the distribution of alkaline phosphatase in cartilage and bone, and the 


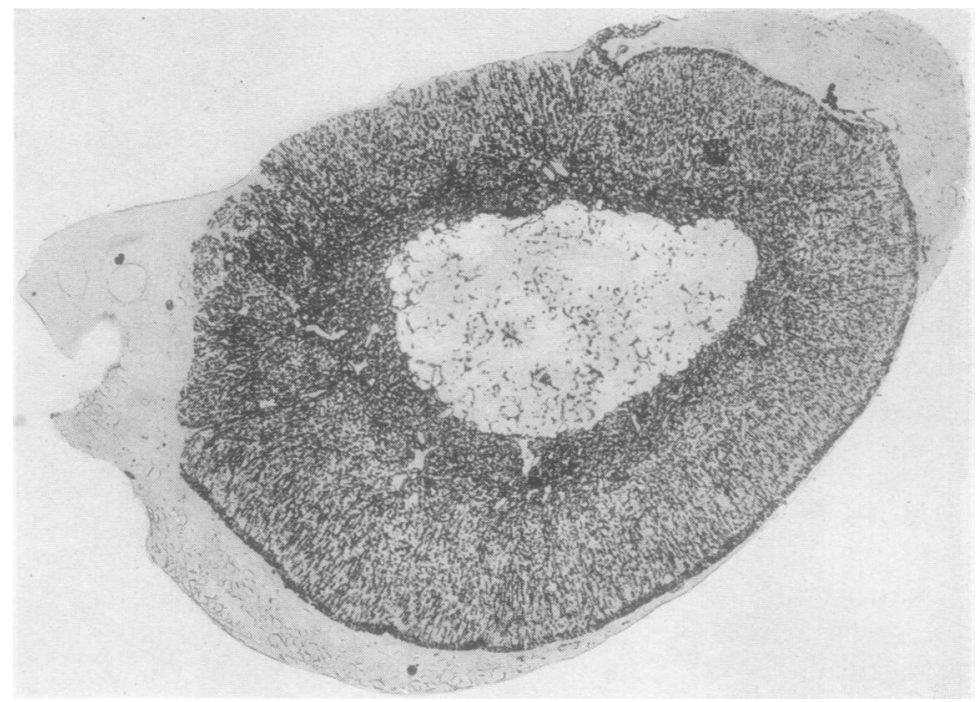

Fig. 24.-Rat adrenal gland incubated for three hours with $\mathbf{M} / 200$ phenyl phosphate at $p \mathbf{H} 9.0$. Disposition of alkaline phosphatase. $\times 19$.

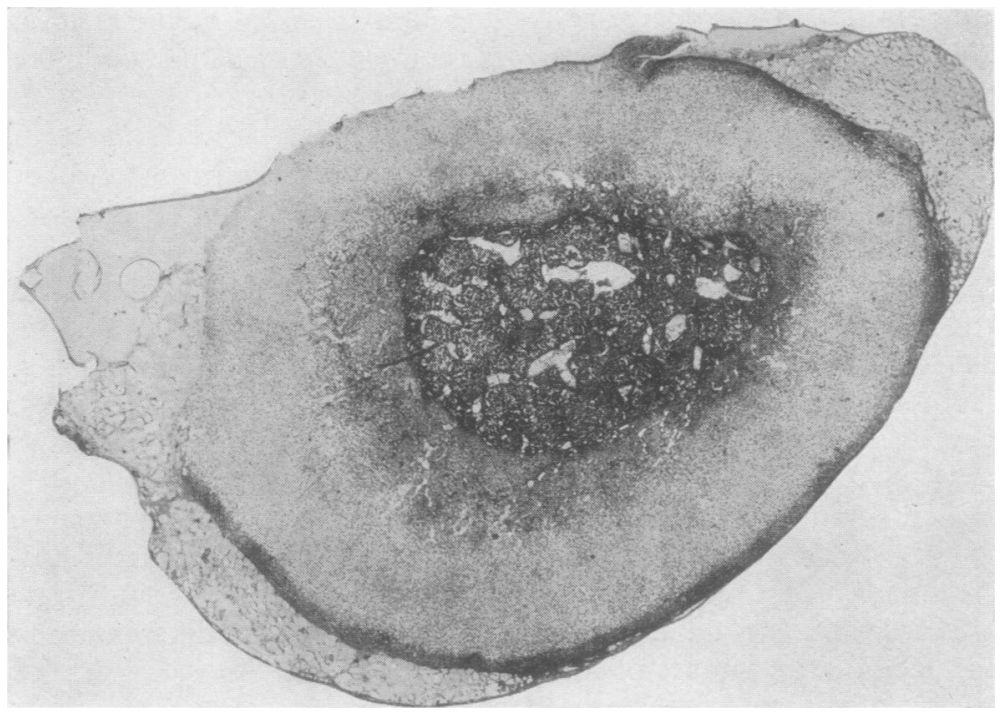

Fig. 25.-Rat adrenal gland incubated for three hours with $M / 200$ adenylic acid at $p H$ 7.5. Disposition of 5 -nucleotidase. $\times 19$.

endometrium has been studied by Atkinson and Gusberg (1948) and by Hall (1950). Wachstein and Zak (1946) dealt particularly with the liver. From these and a large number of unquoted studies it appears that the alkaline phosphatase technique can be applied to various pathological materials to give valuable information as to their nature and function. 


\section{Acid Phosphatases}

Two histochemical techniques exist for the demonstration of acid phosphatases, and neither has achieved the popularity of Gomori's alkaline phosphatase method. The less useful of the two, for histologists, is a variation of the diazo dye technique, described by Seligman and Manheimer (1949), which depends on the hydrolysis of calcium alpha naphthyl phosphate by acid phosphatase at $p \mathrm{H} 5$ and coupling of the liberated alpha naphthol with anthraquinone-1-diazonium chloride. The other method, first described by Gomori (1941b), depends, as in the case of alkaline phosphatase, on the liberation of phosphate ions from organic phosphate. In this case the reaction is buffered at $p \mathrm{H} 4.7$ to 5.0, at which level calcium phosphate will not precipitate. Lead nitrate is therefore used instead of calcium nitrate in the incubating solution, since its phosphate is insoluble at $p \mathbf{H}$ 5.0. Treatment with yellow ammonium sulphide converts the precipitated phosphate into the brown sulphide of lead.

Many workers have found Gomori's acid phosphatase technique to be capricious and unreliable (Moog, 1943a; Hard and Lassek, 1946; Lassek, 1947). This last author found it possible to reproduce acid phosphatase pictures in the sciatic nerve of the cat after mancuvres which certainly destroyed all enzymes. He concluded that the acid phosphatase demonstrated histochemically by means of lead salts was a chemical phenomenon. The recent studies of Newman, Kabat, and Wolf (1950) have indicated that non-specific deposition of lead salts is a serious handicap in enzyme localization between $p \mathrm{H} 5.3$ and 6.8 and that it occurs occasionally at a lower $p \mathrm{H}$. This probably explains Lassek's findings. Gomori (1950c) has given details of an improved acid phosphatase method. He stresses the importance of the ratio of buffer to substrate in improving the constancy of results. It appears that the acid phosphatase technique is a valuable tool in the investigation of pathological conditions provided that two control sections are invariably employed, one inactivated with $\mathrm{M} / 100$ sodium fluoride and the other incubated in a medium containing no substrate.

\section{Methods for Other Enzymes}

A few years ago perhaps three or four enzymes could be demonstrated by histochemical techniques in animal tissues. Excluding the phosphatases, there are now techniques for at least ten. Brief mention of these is all that space allows. Gomori (1948b) described the demonstration of sites of phosphamidase activity, incubating sections at $p \mathbf{H} 5.6$ with p-chloranilidophosphonic acid and lead nitrate. The specific enzyme occurred in small amounts in normal tissue, but in large amounts in grey matter and in malignant epithelial tumours. Newman et al. (1950) considered that part or all of the staining achieved with this method might be due to non-specific deposition of lead. For peroxidases a large number of methods exist empioying either benzidine, which is oxidized to a blue compound, or alpha naphthol. A recent application of the alpha naphthol method to blocks of tissue, as opposed to blood smears, is described by Ritter and Oleson (1947, 1950). Keilin (1933) showed that the "nadi" reaction, producing indophenol blue from alpha naphthol and p-aminodimethylaniline, revealed the presence of cytochrome oxidase-cytochrome $C$, and Lison (1936) observed that the reaction should be carried out on fresh tissues in alkaline solution. Moog (1943b) used the reaction to demonstrate cytochrome oxidase in chick embryos. A method for esterases has been evolved by Nachlas and Seligman (1949) using the diazo dye principle with beta naphthyl acetate and 
diazotized alpha naphthylamine. Gomori (1950b) observes that staining of anomalous sites results with this method, due either to absorption of free naphthol or of the azo dye formed by enzyme action elsewhere. He suggests that more accurate localization can be achieved with alpha naphthyl acetate. Methods for lipases were described by Gomori (1945, 1946b), and elaborated later (1949b). Wachstein (1946) modified Gomori's original method, in which sections are incubated with water-soluble unsaturated or saturated fatty acid esters of polyglycols, in the presence of calcium ions. Insoluble calcium soaps are precipitated at the sites of enzyme activity and visualized by conversion to lead salts and, finally, to lead sulphide. Sneath (1950) considers that the lipase technique is not yet sufficiently reliable for use in diagnostic pathology.

Two independent methods exist for the localization of choline esterase. In the first (Gomori, 1948a) the choline ester of a higher fatty acid (myristoyl choline) is hydrolysed by the enzyme in acetone-fixed sections at $p \mathrm{H} 8$. The resulting free fatty acid is precipitated as its cobalt salt and visualized as sulphide. The authors of the second method (Koelle and Friedenwald, 1949) believed that Gomori's method revealed only non-specific esterases. They incubated fresh frozen sections in a medium containing acetylthiocholine and copper glycinate at $p \mathbf{H} 8$. The reaction product, copper thiocholine, was then converted to brown copper sulphide. Seligman, Nachlas, and Cohen (1950) produced a reaction for sulphatases using potassium-6benzoyl-2-naphthyl sulphate as substrate, and coupling the free naphthyl compound to a diazonium salt in situ. These same authors described a method for betaglucuronidase, using a similar principle, with 6-bromo-2-naphthol glucuronide as substrate. Friedenwald and Becker (1948) used two methods for this enzyme. The first involves the precipitation of the insoluble red hydroxyphenylazo-beta naphthol from its soluble glucuronide by the action of the enzyme in fresh tissue sections. Localization is good and the method comparatively easy; unfortunately, since the red beta naphthol compound is soluble in alcohol and xylol, only watery mounting media can be used. The second method depends on the hydrolysis of 8-hydroxyquinoline glycuronide, precipitation of the free quinoline derivative, and its conversion to the ferric salt which is subsequently visualized by the Prussian-blue reaction. The second method was modified by Campbell (1949) for a study of normal and neoplastic tissues; anaplastic carcinomas of animal origin were particularly rich in the enzyme. The method for amine oxidase introduced by Oster and Schlossman (1942) was based on the oxidation of tyramine to an aldehyde and its visualization by Schiff's reagent. It has been shown by Gomori (1950a) to be quite unspecific. The dopa oxidase technique first described by Bloch (1917) remains in current use, the modification introduced by Laidlaw and Blackberg (1932) being usually employed. Finally, methods exist for demonstrating dehydrogenases in fresh plant and animal tissues. These employ triphenyltetrazolium chloride, or its iodo derivatives, which are reduced to insoluble red formazans (Pratt and Dufrenoy, 1948; Black, Kleiner, and Speer, 1950; Atkinson, Melvin, and Fox, 1950). Rutenberg, Gofstein, and Seligman (1950) have prepared a di-tetrazolium salt which is reduced to a blue formazan, more easily localized than the red compound.

Few of these enzyme methods are ready for general application to pathological problems at the present time, with the exception of those for alkaline phosphatase. No doubt the study of glucuronidase in pathological tissues would yield valuable 
results. But the more specific of the two methods for this enzyme, using hydroxyquinoline glucuronide, is not simple to perform, while with the other method localization is less reliable and permanent preparations cannot be obtained. The dopa oxidase method is reliable, but its application is limited, while the other methods mentioned have not yet reached the stage at which they can reasonably be employed in pathological investigations.

\section{Miscellaneous Methods}

A miscellany of methods of interest to histologists remains to be briefly considered.

Inorganic Anions.-Gersh (1938) described two silver nitrate reagents for visualizing chloride on the one hand and chloride, phosphate, and carbonate on the other in freeze-dried material mounted on slides without contact with water. For this purpose floating out on warm mercury, first suggested by Danielli and used by Harris, Sloane, and King (1950), is particularly suitable.

Inorganic Cations.-The Prussian and Turnbull blue and other methods for iron are critically reviewed by Lillie (1948) and by Bunting (1949), who concludes that the optimum strength of the ferro-cyanide- $\mathrm{HCl}$ mixture for the former method is $2 \%$ of each, applied for one hour at room temperature. The ammonium sulphidedinitroresorcinol method of Humphrey (1935) has the two advantages of permanency and freedom from iron-containing reagents. It is far less sensitive than the Prussianblue test and will not, therefore, be used in critical work. I have not found the 8-hydroxyquinoline method of Thomas and Lavalloy (1935) to be either convenient or reliable. No advances in the technique for demonstration of calcium have been made since Cameron's (1930) review of the methods then available. The method of choice remains that of von Kossa, using control sections freed from calcium by immersion in $0.1 \mathrm{M}$-citrate buffer at $p \mathrm{H} 4.5$ for 10 to 20 minutes. Few other anions or cations are likely to require investigation by the pathologist, although methods exist for gold, silver, bismuth, mercury, palladium, and even less probable elements. The sensitivity and specificity of most methods for inorganic substances leave much to be desired, and any advance in the localization of cations as well as anions seems likely to be made by the use of radioactive isotopes and autoradiography, though the latter has grave drawbacks for high-power work.

Various techniques exist for the autoradiographic detection of organically bound radioactive iodine $\left(\mathrm{I}^{131}\right)$, and they can be carried out by histologists without special difficulty (Bélanger and Leblond, 1946; Evans, 1947; Pelc, 1947; Doniach and Pelc, 1949, 1950). These techniques differ in the manner in which the photographic film or emulsion is applied to the surface of the section containing the radioactive substance. Ordinary histological fixatives are employed and paraffin sections, but contact with water is to be avoided if soluble substances are being studied. Holt, Cowing, and Warren (1949) found considerable loss of radiophosphorus from sections floated out on water. Freeze-dried sections floated out on warm mercury should be ideal for autoradiography, but these authors obtained their best results with alcohol-formalin fixation, dioxane dehydration and clearing, and paraffin embedding.

Two other physical methods, of simple application, are available to the histologist. The polarizing microscope, and the simpler polaroid lenses, remain extremely 
useful for determining the presence of doubly refractile fats, though they cannot give clear information as to the nature of these. Cholesterol esters, phosphatides, cerebrosides, steroids, and formol-fixed neutral fat may all be birefringent. Lison (1936) distinguished between simple illumination by polarized light, indicating fat in a crystalline state, and maltese-cross formation, indicating cholesterides or lipins (phosphatides and cerebrosides). It is as well to remember that other structures such as collagen and keratin (Fig. 26) may also be birefringent. Figs. 23 and 24

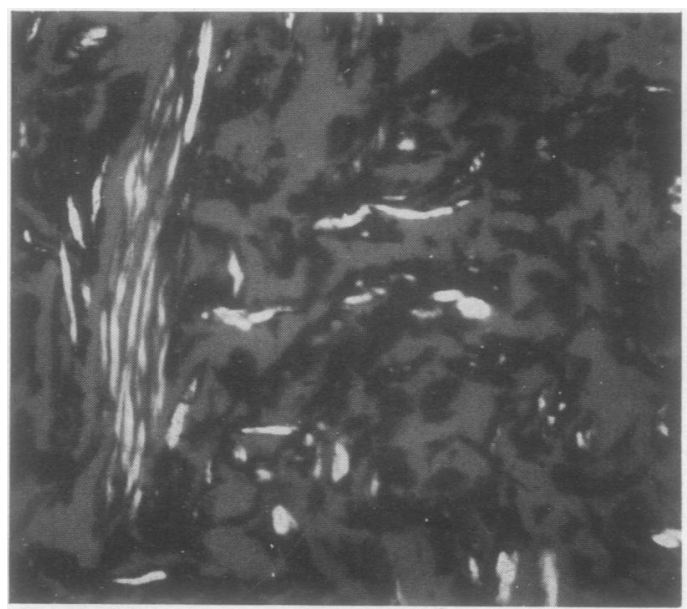

FIG. 26.-Keratin fragments in an epidermoid cyst to show plain birefringence (prisms half rotated).

illustrate the difference between maltese-cross and simple illumination by polarized light. Microscopy using filtered ultra-violet light, from a source such as that suggested by Lempert (1944), has many applications, but few can be considered useful. Natural fluorescence is exhibited by a number of materials in vertebrate tissues when these are exposed to ultra-violet light. The porphyrins may be located by their red fluorescence (Grafflin, 1942; Gillman, Gillman, and Brenner, 1945), the granules of the argentaffin cells by their golden yellow (Jacobson, 1939), vitamin A by its fading green (Popper, 1944), and riboflavin by its greenish-yellow

(Ellinger, 1938). If we except the demonstration of acid-fast bacilli by means of auramine, the staining of tissues with fluorescent dyes and examination by ultra-violet light has nothing to recommend it. It has been used principally by Popper (1944), using phosphine R, for fats and by Szanto and Popper (1948) for ribonucleic acid, making use of the latter's property of quenching the fluorescence of cytoplasm stained with coriophosphin. Ultra-violet fluorescence is a pretty way of demonstrating argentaffin cell granules, but they are far better shown by using a silver method, such as Masson's (1925) Fontana stain, or by coupling with diazonium salts. Fig. 5 shows argentaffin granules stained by the latter method (Cordier and Lison, 1930; Clara, 1935), using the stable diazotate of nitroanisidine (Echtrotsalz B). Gomori (1948c) employed a number of histochemical methods to determine the nature of these granules and concluded that they contained a derivative of resorcinol. In a case of argentaffin carcinoma of the stomach (unpublished) I found that the specific granules in the tumour cells would not reduce Fontana's silver solution in 24 hours and they were detectable only by the diazo method.

In recent years the chemistry of the melanins has been further elucidated, but, so far, their cytochemistry remains unaltered. Their property of reducing silver salts is the only one made use of by histologists and histochemists alike. Mason (1948a) considered melanin to be a polymerized indole derivative, and Lea (1949) noted that Ehrlich's dimethylaminobenzaldehyde reaction was positive for indole and melanogen but negative for fully formed melanin. According to Mason 
TABLE

Recommended Histochemical Methods for Particular Substances

\begin{tabular}{|c|c|c|c|c|c|c|}
\hline \multicolumn{3}{|c|}{ Substance } & Method & Fixation & \begin{tabular}{|l|}
$\begin{array}{c}\text { Frozen } \\
\text { or } \\
\text { Paraffin }\end{array}$ \\
\end{tabular} & References \\
\hline Glycogen & & $\ldots$ & $\overline{\text { Best }}$ & $\begin{array}{l}\text { Cold alcoholic or } \\
\text { various }\end{array}$ & $\mathbf{P}$ & $\begin{array}{l}\text { Lison and Vokaer } \\
\text { (1949) }\end{array}$ \\
\hline $\begin{array}{l}\text { Ascorbic acid } \\
\text { Protein (tyrosir }\end{array}$ & & $\begin{array}{l}. \\
. .\end{array}$ & $\begin{array}{l}\text { Acid silver } \\
\text { Millon }\end{array}$ & $\begin{array}{l}\text { Fresh } \\
\text { Various }\end{array}$ & $\begin{array}{l}F \\
P\end{array}$ & $\begin{array}{l}\text { Bourne (1936) } \\
\text { Bensley and Gersh }\end{array}$ \\
\hline $\begin{array}{l}\text { Protein (tyrosir } \\
\text { Arginine }\end{array}$ & & $\begin{array}{l}. \\
. .\end{array}$ & $\begin{array}{l}\text { Tetrazonium } \\
\text { Sakaguchi }\end{array}$ & $\begin{array}{l}\text { Various } \\
\text { Acetic-alcohol- }\end{array}$ & $\begin{array}{c}P \\
F \text { or } P\end{array}$ & $\begin{array}{l}(1933 b) \\
\text { Danielli (1947) } \\
\text { Serra (1944) }\end{array}$ \\
\hline Thymonucleic & acid & . & Feulgen & Carnoy or various & $\mathbf{P}$ & Bauer $(1932) ; \mathrm{de}$ \\
\hline Ribonucleic ac & & .. & $\begin{array}{c}\text { Ribonuclease, } \\
\text { pyronin }\end{array}$ & Carnoy or mercurial & $\mathbf{P}$ & Brachet $(1940,1942)$ \\
\hline Ribonucleic ac & & & $\begin{array}{l}\text { Perchloric acid } \\
\text { extraction }\end{array}$ & Various & $\mathbf{P}$ & $\begin{array}{l}\text { Erickson, Sax, and } \\
\text { Ogur (1949) }\end{array}$ \\
\hline Purines: Pyri & imidine & & $\begin{array}{c}\text { Benzoylation and } \\
\text { tetrazonium }\end{array}$ & Various & $\mathbf{P}$ & Danielli (1947) \\
\hline Mucins .. & . & & P.A.S. & Various & $\mathbf{P}$ & $\begin{array}{l}\text { Hotchkiss (1948); } \\
\text { McManus (1946b) }\end{array}$ \\
\hline Mucoprotein & 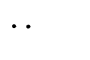 & .. & P.A.S. & $\begin{array}{l}\text { Preferably formalin- } \\
\text { containing }\end{array}$ & $F$ or $P$ & Hotchkiss (1948) \\
\hline $\begin{array}{l}\text { Mucopolysaccl } \\
\text { M.P.S. includin } \\
\text { onic acid }\end{array}$ & $\begin{array}{l}\text { harides } \\
\text { ng hyal }\end{array}$ & & $\begin{array}{l}\text { Metachromasia } \\
\text { Metachromasia }\end{array}$ & $\begin{array}{l}\text { Various } \\
\text { Basic lead acetate }\end{array}$ & $\mathbf{F} \underset{\mathbf{P}}{\operatorname{or}} \mathbf{P}$ & $\begin{array}{l}\text { Lison (1936) } \\
\text { Holmgren and } \\
\text { Wilander (1937) }\end{array}$ \\
\hline Hyaluronic aci & & . & $\begin{array}{l}\text { Dialysed iron } \\
\text { hyaluronidase }\end{array}$ & Carnoy & $\mathbf{P}$ & Hale (1946) \\
\hline Hyaluronic aci & & .. & $\begin{array}{l}\text { Metachromasia } \\
\text { hyaluronidase }\end{array}$ & Formalin or jelly & $\mathbf{P}$ & $\begin{array}{l}\text { Penney and Balfour } \\
\text { (1949) }\end{array}$ \\
\hline Mucopolysacch & harides & & $\begin{array}{l}\text { Basophilia } \\
\text { (quantitative) }\end{array}$ & Formol-mercury & $\mathbf{P}$ & $\begin{array}{l}\text { Dempsey and Singer } \\
\text { (1946) }\end{array}$ \\
\hline Neutral fats & . & . & Sudan III and IV & Formalin & $\mathbf{F}$ & $\begin{array}{l}\text { Kay and Whitehead } \\
\text { (1941) }\end{array}$ \\
\hline $\begin{array}{l}\text { Phospholipid } \\
\text { Phospholipid } \\
\text { Phospholipid }\end{array}$ & $\begin{array}{l}\cdots \\
\cdots \\
\cdots\end{array}$ & $\begin{array}{l}. . \\
\cdots \\
.\end{array}$ & $\begin{array}{l}\text { Sudan black B } \\
\text { Acid haematin } \\
\text { Pyridine extraction }\end{array}$ & $\begin{array}{l}\text { Formol-calcium } \\
\text { Formol-calcium } \\
\text { Weak Bouin }\end{array}$ & $\begin{array}{l}\mathbf{P} \\
\mathbf{P} \\
\mathbf{P}\end{array}$ & $\begin{array}{l}\text { McManus (1946a) } \\
\text { Baker (1947) } \\
\text { Baker (1947) }\end{array}$ \\
\hline Glycoli & rebrosic & & P.A.S. & Formalin & $\mathbf{P}$ & Morrison and Hack \\
\hline Lipoids .. & .. & .. & $\begin{array}{l}\text { Selective extrac- } \\
\text { tion }\end{array}$ & $\begin{array}{l}\text { Fresh (fixed by ex- } \\
\text { tractive) }\end{array}$ & $\mathbf{P}$ & Keilig (1944) \\
\hline Cholesterol & $\cdots$ & .. & $\begin{array}{l}\text { Liebermann- } \\
\text { Burchardt }\end{array}$ & Formalin & $\mathrm{F}$ & $\begin{array}{l}\text { Schultz (1925a, } \\
\text { 1925b) }\end{array}$ \\
\hline Ketosteroids & . & .. & $\begin{array}{c}\text { Naphthoic acid } \\
\text { hydrazide }\end{array}$ & Formalin & F & $\begin{array}{l}\text { Ashbel and Seligman } \\
\text { (1949) }\end{array}$ \\
\hline $\begin{array}{l}\text { Alkaline phosp } \\
\text { Alkaline phosp }\end{array}$ & $\begin{array}{l}\text { phatase } \\
\text { phatase }\end{array}$ & & $\begin{array}{l}\text { Calcium-cobalt } \\
\text { Calcium-silver }\end{array}$ & $\begin{array}{l}\text { Cold acetone } \\
\text { Cold acetone }\end{array}$ & $\begin{array}{l}\mathbf{P} \\
\mathbf{P}\end{array}$ & $\begin{array}{l}\text { Gomori (1946a) } \\
\text { Kabat and Furth } \\
(1941)\end{array}$ \\
\hline $\begin{array}{l}\text { Acid phosphat } \\
\text { Peroxidase }\end{array}$ & & $\begin{array}{l}\ldots \\
\ldots\end{array}$ & $\begin{array}{l}\text { Calcium-lead } \\
\text { Block technique }\end{array}$ & $\begin{array}{l}\text { Cold acetone } \\
\text { Formol-alcohol }\end{array}$ & $\begin{array}{l}\mathbf{P} \\
\mathbf{P}\end{array}$ & $\begin{array}{l}\text { Gomori (1950c) } \\
\text { Ritter and Oleson } \\
\text { (1947) }\end{array}$ \\
\hline Glucuronidase & & .. & Hydroxyquinoline & Fresh & $\mathbf{F}$ & $\begin{array}{l}\text { Friedenwald and } \\
\text { Becker (1948) }\end{array}$ \\
\hline a oxidase & . & .. & Do & Fresh & $\mathbf{F}$ & $\begin{array}{l}\text { Laidlaw and Black- } \\
\text { berg (1932) }\end{array}$ \\
\hline Iron & & .. & Prussian blue & $\begin{array}{l}\text { Neutral formalin or } \\
\text { various }\end{array}$ & $\mathbf{P}$ & Bunting (1949) \\
\hline$I^{131}$ & *. & -. & Autoradiograph & Alcohol & $\mathbf{P}$ & $\begin{array}{c}\text { Doniach and Pelc } \\
(1949 a)\end{array}$ \\
\hline $\begin{array}{l}\text { Argentaffin gra } \\
\text { Argentaffin gra }\end{array}$ & $\begin{array}{l}\text { anules } \\
\text { anules }\end{array}$ & $\begin{array}{l}\ldots \\
\cdots\end{array}$ & $\begin{array}{l}\text { Diazo } \\
\text { Hexamine-silver }\end{array}$ & $\begin{array}{l}\text { Formalin-containing } \\
\text { Formalin-containing }\end{array}$ & $\begin{array}{l}\mathbf{P} \\
\mathbf{P}\end{array}$ & $\begin{array}{l}\text { Jacobson (1939) } \\
\text { Gomori (1948c) }\end{array}$ \\
\hline
\end{tabular}


(1948b) melanin is soluble in alcohol, pyridine, or ethylene chlorohydrin after separation from its protein component. Taft (1949), however, used all these solvents at 22 and $66^{\circ} \mathrm{C}$. for up to 24 hours on fixed paraffin sections and unfixed frozen sections without observing any diminution in the amount of melanin present. Oxidation remains the only satisfactory method for removing the colour of melanin, either for diagnostic purposes or where it interferes with the interpretation of another reaction, that for phosphatases, for instance. Three methods are in current use; $1 / 2,000$ permanganate for 24 hours, potassium chlorate in acid alcohol for 15 minutes, and 10 vol. hydrogen peroxide for 24 hours. The last is the most reliable. Of the remaining pigments, only bilirubin is of sufficient interest to be noted here. Of the positive histochemical tests for this substance, Gmelin's nitric acid reaction is too violent and Stein's (1935) iodine test neither reliable nor specific. Negative tests, such as the failure to react with ferrocyanide- $\mathrm{HCl}$ or ammoniacal silver, and the stability of the pigment to hydrogen peroxide, coupled with staining by means of methylene blue or iron haematoxylin, are usually considered sufficient.

\section{Summary}

In this review I have attempted to mention and partly to explain those methods of histochemistry, in use at the present time, which can reasonably be employed by practising histologists. The accompanying photomicrographs were chosen not only to illustrate particular sections of the review but also, and this refers especially to the coloured figures, to indicate that modern histochemical techniques can produce results which bear comparison with those given by conventional staining methods (Plate I, Fig. 6). The application of the methods described to everyday problems, of functional as well as of structural pathology, can only result in increased understanding of both. It is, therefore, essential that these histochemical techniques should be applied not only by specialists, whose interests are often narrow and restricted, but by those who have access to the materials and problems of everyday pathology.

The Table on page 29 takes the place of a more conventional summary. It is a list of recommended methods for particular substances, together with the appropriate fixatives and the main references. The absence of a method from the Table does not mean that it is unworkable, and methods have been included which are useful although their specificity is open to doubt. Where many methods are available that considered best has been chosen. The references given are not necessarily those of the original author. They have been selected with a view to rapid appreciation of the technical details of the method to which they refer.

I should like to acknowledge the great help I have received, in compiling the historical part of this review, from Miss D. F. Atkins, Librarian at the Postgraduate Medical School, and from Mr. F. N. L. Poynter, Assistant Librarian of the Wellcome Research Library.

For the reproduction of the portrait of Raspail I am indebted to the kindness of Mr. A. M. Vidal-Hall, of the Scientific Office of the French Embassy.

With two exceptions, all the photomicrographs were taken by Mr. E. V. Wilmott, F.R.P.S., and I am especially grateful to him for the skill with which he has demonstrated these often 
difficult subjects. I wish to thank Mr. K. G. Moreman for the photomicrographs reproduced in Figs. 23 and 24.

I have received liberal assistance from Messrs. J. G. Griffin and D. Taplin in the preparation of paraffin and frozen sections and from Mr. L. J. Wright in the preparation of freeze-dried sections. The latter process was made possible by grants from the Research Fund of the University of London.

\section{REFERENCES}

Abolins, L. (1948). Nature, Lond., 161, 556. and Abolins, A. (1949). Ibid.. 164, 455.

Albert, S., and Leblond, C. P. (1946). Endocrinology, 39, 386.

Alsterberg, G. (1941). Z. Zellforsch. A., 31, 364.

Altmann, R. (1886). Studien über die Zelle. Leipzig. (1889). Arch. Anat. Physiol., Lpz., Physiol. Abt., p. 524.

Arzac, J. P. (1947). Analecta méd., 8, No. 2, p. 9.

- and Flores, L. G. (1949). Stain Tech., 24, 25.

Ashbel, R., and Seligman, A. M. (1949). Endocrinology, 44, 565.

Atkinson, E., Melvin, S., and Fox, S. W. (1950). Science, 111, 385.

Atkinson, W. B., and Gusberg, S. B. (1948). Cancer, 1, 248.

Baker, J. R. (1943). J. Quekett micr. Cl., 4 ser., 1, 256.

- (1944). Quart. J. micr. Sci., 85, 1.

- (1945). Cytological Technique, 2nd ed. London.

(1946). Quart. J. micr. Sci., 87, 441.

- (1947). Quart. J. micr. Sci., 88, 115.

Baker, R. D., and Kent, S. P. (1950). Arch. Path., 49, 568.

Barnett, S. A., Bourne, G., and Fisher, R. B. (1941). Nature, Lond., 147, 542.

Baud, C. A. (1948). Ibid., 161, 559.

Bauer, H. (1932). Z. Zellforsch., 15, 225.

(1933). Z. mikr.-anat. Forsch., 33, 143.

Bauer, K. F. (1943). Z. wiss. Mikr., 59, 142.

Beale, L. S. (1861). Arch. Med., Lond., $2,179$.

Bélanger, L. F., and Leblond, C. P. (1946). Endocrinology, 39, 8.

Belfanti, S., Contardi, A., and Ercoli, A. (1935). Biochem. J., $29,842$.

Bencke, A. (1862). Korrespbl. Ver. gemeinsch. Arbeiten, 59, 980.

Bennett, H. S. (1939). Proc. Soc. exp. Biol., N.Y., 42, 786.

(1940). Amer. J. Anat. 67, 151.

(1948). Abstr. Amer. Ass. Anat., Anat. Rec., 100, 640.

and Yphantis, P. A. (1948). J. Amer. chem. Soc., 70, 3522.

Bensley, C. M. (1939). Stain Tech., 14, 47.

Bensley, R. R. (1933). Anat. Rec., 58, 1.

and Gersh, I. (1933a). Ibid., 57, 205. (1933b). Ibid., 57, 217. and Hoerr, N. L. (1934). Ibid., 60, 251.

Bernard, C. (1859). Leçons sur les Propriétés Physiologiques et les Altérations Pathologiques des Liquides de l'Organisme, vol. 2. Paris.

- (1877). Leçons sur le Diabète. Paris.

Best, F. (1906). Z. wiss. Mikr., 23, 319.

Bierry, H., and Gouzon, B. (1936). C.R. Acad. Sci., Paris, 202, 686.

Black, M. M., Kleiner, I. S., and Speer, F. D. (1950). Cancer Res., 10, 204.

Bloch, B. (1917). Arch. Derm. Syph., Wien, 124, 129.

Bodansky, O. (1937). J. biol. Chem., 118, 341.

Boscott, R. J., and Mandl, A. M. (1949). J. Endocrinol., 6, 132.

Bourne, G. (1933). Nature, Lond., 131, 874. (1936). Anat. Rec., 66, 369. (1943). Quart. J. exp. Physiol., 32; 1.

Brachet, J. (1940). C.R. Soc. Biol., Paris, 133, 88. (1942). Arch. Biol., Paris, 53, 207. (1946). Experientia, Basel, 2, 142.

Brandenburg, K. (1900). Münch. med. Wschr., 47, 183.

Bunge, G. (1887). Lehrbuch der physiologischen und pathologischen Chemie. Leipzig: F. C. W. Vogel. 
Bunting, H. (1948). Proc. Soc. exp. Biol., N.Y., 67, 370. (1949). Stain Tech., 24, 109. and White, R. F. (1950). Arch. Path., 49, 590.

Cain, A. J. (1947). Quart. J. micr. Sci., 88, 383.

Camber, B. (1949). Nature, Lond., 163, 285.

Cameron, G. R. (1930). J. Path. Bact., 33, 929.

Campbell, J. G. (1949). Brit. J. exp. Path., 30, 548.

Carleton, H. M. (1926). Histological Technique, p. 167. Oxford Univ. Press.

Carr, J. G. (1945). Nature, Lond., 156, 143.

Caspersson, T., Hammarsten, E., and Hammarsten, H. (1935). Trans. Faraday Soc., $31,367$.

Catchpole, H. R. (1949). J. Endocrinol., 6, 218.

Caventou, J. B. (1826). Ann. Chim. Phys., 31, 337.

Chabaud, A. (1942). Ann. Inst. Pasteur, 68, 106.

Chamot, E. M., and Mason, C. W. (1930). Handbook of Chemical Microscopy. New York.

Choudhuri, H. C. (1943). Nature, Lond., 152, 475.

Clara, M. (1935). Z. wiss. Mikr., 51, 316.

Colin, J. J., and de Claubry, H. G. (1814). Ann. Chim., 90, 87.

Cordier, R., and Lison, L. (1930). Bull. Histol. Tech. micr., 7, 140.

Cornil, V. (1875). C.R. Acad. Sci., Paris, 80, 1288.

Daddi, L. (1896). Arch. ital. Biol., 26, 143.

Danielli, J. F. (1946). J. exp. Biol., 22, 110. (1947). Symp. Soc. exp. Biol., 1, 101.

- (1950a). Cold Spr. Harb. Symp. quant. Biol., 14, 32.

- (1950b). Nature, Lond., 165, 762.

Davidson, J. N., and Waymouth, C. (1944). Biochem. J., 38, 39.

Deane, H. W. (1947). Amer. J. Anat., 80, 321. and Greep, R. O. (1946). Ibid., 79, 117.

- Nesbett, F. B., and Hastings, A. B. (1946). Proc. Soc. exp. Biol., N.Y., 63, 401.

Dempsey, E. W. (1949). Ann. N.Y. Acad. Sci., 50, 336. and Bassett, D. L. (1943). Endocrinology, 33, 384.

— Bunting, H., Singer, M., and Wislocki, G. B. (1947). Anat. Rec., 98, 417. and Deane, H. W. (1946). J. cell. comp. Physiol., 27, 159.

— and Singer, M. (1946). Endocrinology, 38, 270. and Wislocki, G. B. (1950). Stain Tech., 25, 73. and Wislocki, G. B. (1946). Physiol. Rev., 26, 1. (1947). Amer. J. Anat., 80, 1.

Dodson, E. O. (1946). Stain Tech., $21,103$.

Doniach, I., and Pelc, S. R. (1949). Proc. roy. Soc. Med., 42, 957. (1950). Brit. J. Radiol., 23, 184.

Doyle, W. L. (1950). Fed. Proc., 9, 34.

Ehrlich, P. (1878-9). Verh. physiol. Ges. Berlin., 20.

_- (1883). Z. Klin. Med., 6, 33 . Das Sauerstoff-Bedü -fniss des Organismus. Berlin.

Ellinger, P. (1938). Biochem. J., 32, 376.

Emmel, V. M. (1946). Anat. Rec., 95, 159.

Eränkö, O. (1950). Nature, Lond., 165, 116.

Erickson, R. O., Sax, K. O., and Ogur, M. (1949). Science, 110, 472.

Evans, T. C. (1947). Proc. Soc. exp. Biol., N.Y., 64, 313.

Everett, J. W. (1945). Amer. J. Anat., 77, 293.

Feigin, I., Wolf, A., and Kabat, E. A. (1950). Amer. J. Path., 26, 647.

Feulgen, R., and Rossenbeck, H. (1924). Z. phys. Chem., 135, 203. and Voit, K. (1924). Pfiug. Arch. ges. Physiol., 206, 389.

Feyrter, F. (1936). Virchows Arch., 296, 645.

Fisher, I., and Glick, D. (1947). Proc. Soc. exp. Biol., N.Y., 66, 14.

Flemming, W. (1876). Arch. mikr. Anat., 12, 434. (1882). Zellsubstanz, Kern und Zelltheilung. Leipzig.

Follis, R. H. (1949). Bull. Johns Hopk. Hosp., 85, 360.

Foster, C. F., and Wilson, R. R. (1951). Nature, Lond., in press.

Frey, H. (1867). Handbuch der Histologie und Histochemie des Menschen. Leipzig. (1874). Histology and Histochemistry of Man, trans. Barker, A. E. J. London.

Friedenwald, J. S. (1947). Cold Spr. Harb. Symp. quant. Biol., 12, 141.

- and Becker, B. (1948). J. cell. comp. Physiol., 31, 303.

- and Maengwyn-Davies, G. D. (1950). Fed. Proc., 9, 44.

Gerebtzoff, M. A., Dallemagne, M. J., and Philippot, E. (1950). Nature, Lond., 165, 572. 
Gersh, I. (1932). Anat. Rec., 53, 309.

- (1938). Ibid., 70, 311.

(1948). Bull. int. Ass. med. Mus., 28, 179.

(1949a). J. Endocrinol. 6, 282.

(1949b). Arch. Path., 47, 99.

Gibb, R. P., and Stowell, R. E. (1949). B'ood, 4, 569.

Gillman, J., Gillman, T., and Brenner, S. (1945). Nature, Lond., 156, 689.

Giroud, A., and Leblond, C. P. (1936). Ibid., 138, 247.

Glick, D. (1946). Science, 103, 599.

(1949). Techniques of Histo- and Cyto-chemistry. New York.

Gomori, G. (1939). Proc. Soc. exp. Biol., N.Y., 42, 23.

- (1941a). J. cell. comp. Physiol., 17, 71.

(1941b). Arch. Path., 32, 189.

(1942). Proc. Soc. exp. Biol., N.Y., 51, 133.

(1945). Ibid., 58, 362 .

(1946a). Amer. J. clin. Path., 16, Tech. Sect., 7, 177.

(1946b). Arch. Path., 41, 121.

(1946c). Amer. J. clin. Path., 16, 347.

(1948a). Proc. Soc. exp. Biol., N.Y., 68, 354.

(1948b). Ibid., 69, 407 .

(1948c). Arch. Path., 45, 48.

(1949a). Proc. Soc. exp. Biol., N.Y., 72, 449.

(1949b). Ibid., 72, 697 .

(1950a). Ann. N.Y. Acad. Sci., 50, 968.

(1950b). J. Lab. clin. Med., 35, 802.

(1950c). Stain Tech., 25, 81 .

Goodspeed, T. H., and Uber, F. M. (1934). Proc. Nat. Acad. Sci., Wash., $20,495$.

(1935). Univ. Calif. Publ. Bot., 18, 23.

Gould, B. S. (1944). J. biol. Chem., 156, 365 .

Grafflin, A. L. (1942). Amer. J. Anat., 71, 43.

Gram, C. (1884). Fortschr. Med., $2,185$.

Greep, R. O., and Deane, H. W. (1949). Ann. N.Y. Acad. Sci., 50, 596.

Griesbach, H. (1886). Z. wiss. Mikr., $3,358$.

Hack, M. H. (1949). Personal communication, quoted by Gersh, 1949.

Hale, C. W. (1946). Nature, Lond., 157, 802.

Hall, J. E. (1950). Amer. J. Obstet. Gynec., 60, 212.

Hamperl, H. (1934). Virchows Arch., 292, 1.

Hard, W. L., and Lassek, A. M. (1946). J. Neurophysiol., 9, 121.

Hardy, W. B., and Wesbrook, F. F. (1895). J. Physiol., 18, 490.

Harris, J. E., Sloane, J. F., and King, D. T. (1950). Nature, Lond., 166, 25.

Heidenhain, R. (1868). Stud. physiol. Inst. Breslau, 4, 88. (1870). Arch. mikr. Anat., 6, 368.

Heine, L. (1895-6). Hoppe-Szyl. Z., 21, 494.

Hempelmann, L. H. (1940). Anat. Rec., 78, 197.

Henry, H., and Stacey, M. (1943). Nature, Lond., 151, 671.

Hertwig, G. (1929). "Histochemische methoden." In von Möllendorff's Handbuch der mikroskopische Anatomie des Menschen. Brrlin.

Hess, M., and Hollander, F. (1947). J. Lab. clin. Med., 32, 905.

Hoerr, N. L. (1936). Anat. Rec., 65, 293.
and Bensley, R. R. (1936). Ibid., 65, 417.

Hoffmann, R. (1853). Ann. Chem. Pharm., 87, 123.

Holmgren, H., and Wilander, O. (1937). Z. mikr.-anat. Forsch., 42, 242.

Holt, M. W., Cowing, R. F., and Warren, S. (1949). Science, 110, 328.

Hotchkiss, R. D. (1948). Arch. Biochem., 16, 131.

Hoyer, H. (1890). Arch. mikr. Anat., 36, 310.

Hudack, S., Blunt, J. W., Higbee, P., and Kearin, G. M. (1949). Proc. Soc. exp. Biol., N.Y., $72,526$.

Humphrey, A. A. (1935). Arch. Path., 20, 256.

Jacobson, W. (1939). J. Path. Bact., 49, 1.

Jacoby, F., and Martin, B. F. (1949). Nature, Lond., 163, 875.

Kabat, E. A., and Furth, J. (1941). Amer. J. Path., 17, 303.

Kaufmann, B. P., Gay, H., and McDonald, M. R. (1950). Cold Spr. Harb. Symp. quant. Biol., 14, 85 .

_ McDonald, M., and Gay, H. (1948). Nature, Lond., 162, 814.

$$
\text { C }
$$


Kay, W. W., and Whitehead, R. (1934). J. Path. Bact., 39, 449.

- (1935). Ibid., 41, 303.

Keilig, I. (1944). Ibid., 53, 279.

Keilin, D. (1933). Ergebn. Enzymforsch., 2, 239.

Klebs, E. (1868). Z. med. Wiss., 6, 417.

Klein, G. (1929). Praktikum der Histochemie. Berlin.

Koelle, G. B., and Friedenwald, J. S. (1949). Proc. Soc. exp. Biol., N.Y., $70,617$.

Kóssa, J. von (1901). Beitr. path. Anat., 29, 163.

Kossel, A. (1882). Hoppe-Seyl. Z., 7, 7. (1886). Ibid., 10, 248. and Mathews, A. (1898). Ibid., 25, 190.

Laidlaw, G. F., and Blackberg, S. N. (1932). Amer. J. Path., 8, 491.

Lassek, A. M. (1947). Stain Tech., $22,133$.

Lea, A. J. (1949). Arch. Path., 47, 211.

Leach, E. H. (1938). J. Path. Bact., 47, 635.

Lehmann, C. G. (1842). Lehrbuch der physiologischen Chemie. Leipzig.

- (1851). Physiological Chemistry, trans. Day, G. E. London.

- (1883). Traité de Chimie Physiologique. Paris.

Leitgeb, H. (1888). Mitt. bot. Inst. Graz., p. 113.

Lempert, H. (1944). Lancet, 2, 818.

Lendrum, A. C. (1947). In Recent Advances in Clinical Pathology, p. 442. London.

Leulier, A., and Revol, L. (1930). Bull. Histol. Tech. micr., 7, 241.

Levine, N. D. (1940). Stain Tech., 15, 91.

$\mathrm{Li}$, Chong-Fu, and Stacey, M. (1949). Nature, Lond., 163, 538.

Liebermann, L. (1887). Z Zbl. med. Wiss., 25, 321.

Lilienfeld, L. (1893). Arch. Anat. Physiol., Leip., Physiol. Abt., p. 554. and Monti, A. (1892). Z. wiss. Mikr., 9, 332.

Lillie, R. D. (1947). J. Lab. clin. Med., 32, 910.

- (1948). Histopatho'ogical Technic. Philadelphia.

-

- and Mowry, R. W. (1949). Bull. int. Ass. med. Mus., 30, 91.

Linderström-Lang, K. (1936). Arch. exp. Zellforsch., 19, 231.

Lison, L. (1935a). Arch. Biol., Paris, 46, 599.

- (1935b). Bull. Histol. Tech. micr., 12, 279.

- (1936). Histochimie Animale. Paris.

- (1948). Bull. Histol. Tech. micr., 25, 23.

- and Vokaer, R. (1949). Ann. Endocrinol., Paris, 10, 66.

List, J. H. (1885). Z. wiss. Mikr., 2, 145.

Macallum, A. B. (1895). Quart. J. micr. Sci., 38, 175. (1908). Ergebn. Physiol., 7, 552.

Mall, F. (1891). Abh. Sächs. Ges. (Akad.) Wiss. Math-phys., 17, 299.

Mancini, R. E. (1944). Arch. Soc. argent. Anat. norm. patol., 6, 628.

Manheimer, L. H., and Seligman, A. M. (1949). J. nat. Cancer Inst., 9, 181.

Mann, G. (1890). Trans. bot. Soc. Edinb., 18, 429. (1902). Physiological Histology. Oxford.

Marchese, S. (1947). Atti Soc. lombarda Sci. med. biol., 2, 1.

Marchi, V. (1892). Arch. ital. Biol., 17, 191.

Mason, H. S. (1948a). J. biol. Chem., 172, 83. (1948b). In Biology of Melanomas, N.Y. Acad. Sci. Publications, 4, 399.

Masson, P. (1925). Ann. Anat. path., 2, 323.

Mathews, A. (1898). Amer. J. Physiol., 1, 445.

McManus, J. F. A. (1945). Nature, Lond., 156, 173. (1946a). J. Path. Bact., 58, 93.

- - (1946b). Nature, Lond., 158, 202.

- and Findley, L. (1949). Surg. Gynec. Obstet., 89, 616.
- and Mowry, R. W. (1948). Bull. int. Ass. med. Mus., $28,80$.

Menten, M. J., Junge, J., and Green, M. H. (1944). J. biol. Chem., 153, 471.

Meyer, K. (1943). Advanc. Enzymol., 3, 109. (1947). Physiol. Rev., 27, 335.

Michaelis, L. (1901). Virchows Arch., 164, 263.

- (1947). Cold Spr. Harb. Symp. quant. Biol., 12, 142. and Granick, S. (1945). J. Amer. chem. Soc., 67, 1212

Miescher, F. (1871). Hoppe-Seyl. med.-chem. Untersuch., p. 441. 
Miescher, F. (1873). Verh. naturf. Ges. Basel, 6, 138.

Millon, A. N. E. (1844). C.R. Acad. Sci., Paris, 18, 1041.

Mirsky, A. E., and Pollister, A. W. (1946). J. gen. Physiol., 30, 117.

Mitchell, A. J., and Wislocki, G. B. (1944). Anat. Rec., 90, 261.

Mitchell, J. S. (1942). Brit. J. exp. Path., 23, 296.

Molisch, H. (1893). Ber. dtsch. bot. Ges., 11, 73.

Moog, F. (1943a). Proc. Nat. Acad. Sci., Wash., 29, 176. (1943b). J. cell. comp. Physiol., 22, 223.

Morrison, R. W., and Hack, M. H. (1950). Arch. Path., 25, 597.

Nachlas, M. M., and Seligman, A. M. (1949). J. nat. Cancer Inst., 9, 415.

Newman, W., Feigin, I., Wolf, A., and Kabat, E. A. (1950). Amer. J. Path., 26, 257. Kabat, E. A., and Wolf, A. (1950). Ibid., 26, 489.

Ogur, M., and Rosen, G. (1949). Fed. Proc., 8, 234.

Oster, K. A., and Mulinos, M. G. (1944). J. Pharmacol., 80, 132.

and Schlossman, N. C. (1942). J. cell. comp. Physiol., $20,373$.

Overend, W. G., and Stacey, M. (1949). Nature, Lond., 163, 538.

Packer, D. M., and Scott, G. H. (1942). Bull. int. Ass. med. Mus., 22, 85.

Parat, M. (1927). Biol. Rev., 2, 285.

Patzelt, V. (1928). In Fortschritte der Mikrochemie, ed. Klein, G., and Strebinger, R. Vienna.

Payen, A. (1843). Mém. Acad. Sci., Paris, p. 163.

Pearse, A. G. E. (1949). J. clin. Path., $2,81$. (1950a). J. Path. Bact., 62, 351. (1950b). Lancet, $1,954$.

Pelc, S. R. (1947). Nature, Lond., 160, 749.

Penney, J. R., and Balfour, Brigid M. (1949). J. Path. Bact., 61, 171.

Perls, M. (1867). Virchows Arch., 39, 42.

Pischinger, A. (1926). Z. Zellforsch., 3, 169. (1927). Pflüg. Arch. ges. Physiol., 217, 205. (1943). Z. mikr. anat. Forsch., 53, 46.

Policard, A., and Okkels, H. (1932). "Die Mikroveraschung als histochemische Hilfsmethode." In Abderhalden's Handbuch der biologischen Arbeitsmethoden. Berlin.

Pollacci, G. (1900). Atti Ist. bot. Univ. Pavia, 2 ser., 6, 15.

Popják, G. (1944). J. Path. Bact., 56, 485.

Popper, H. (1944). Physiol. Rev., 24, 205.

Pratt, R., and Dufrenoy, J. (1948). Stain Tech., 23, 137.

Pretl, K. (1948). Virchows Arch., 315, 229.

Quinke, H. I. (1868). Referred to in Arch. exp. Path. Pharmak. Lpz., 37, 183, $1895-6$.

Rafalko, J. S. (1946). Stain Tech., 21, 91.

Raspail, F. V. (1825a). Ann. Sci. nat., 6, 224.

(1825b). Ibid., 6, 384.

- (1829). Ann. Sci. Observation, 1, 72.

- (1830). Essai de Chimie Microscopique Appliquée à la Physiologie. Paris.

(1833). Nouveau Système de Chimie Organique. Paris.

(1834). A New System of Organic Chemistry, trans. Henderson, W. London.

Reichstein, T., and Shoppee, C. W. (1943). Vitamins and Hormones, 1, 345.

Reis, J. (1937). Enzymologia, 2, 110. (1940). Bull. Soc. Chim. biol., Paris, 22, 36.

Reis, J. L. (1950). Proc. Biochem. Soc., Biochem. J., 46, p. xxi.

Ritter, H. B., and Oleson, J. J. (1947). Arch. Path., 43, 330. (1950). Amer. J. Path., 26, 639.

Robin, C., and Verdeil, F. (1853). Traité de Chimie anatomique. Paris: J. B. Baillière.

Romeis, B. (1932). " Histochemische methoden." In Boehm and Oppel's Taschenbuch der mikroskopischen Technik. Munich.

Rutenburg, A. M., Gofstein, R., and Seligman, A. M. (1950). Cancer Res., 10, 113.

Ruyter, J. H. C., and Neumann, H. (1949). Biochim. biophys. Acta, Amst., 3, 125.

Saint-Hilaire, C. (1898). Hoppe-Seyl. Z., 26, 102.

Schlossberger, J. E. (1856). Die Chemie der Gewebe des gesammten Thierreichs. Leipzig.

Schneider, W. C. (1945). J. biol. Chem., 161, 293.

Schultz, A. (1925a). Zbl. allg. Path. path. Anat., 36, 529. (1925b). Verh. dtsch. path. Ges., $20,120$.

Schultze, M. (1861). Arch. Anat. Physiol., Lpz., p. 1.

Schwarz, F. (1887). Beitr. Biol. Pf., 5, 1.

Scott, G. H. (1933). Protoplasma, 20, 133.

— and Williams, P. S. (1936). Anat. Rec., 66, 475. 
Seligman, A. M., and Manheimer, L. H. (1949). J. nat. Cancer Inst., 9, 427.

- Nachlas, M. M., and Cohen, R. (1950). Cancer Res., 10, 240.

Serra, J. A. (1944). Naturwissenschaften, 32, 46. (1946). Stain Tech., 21, 5.

and Queiroz-Lopes, A. (1945). Port. Acta biol., 1, 111.

Seshachar, B. R., and Flick, E. W. (1949). Science, 110, 659.

Sevag, M. G., Smolens, J., and Lackman, D. B. (1940). J. biol. Chem., 134, 523.

Sheehan, H. L. (1939). J. Path. Bact., 49, 580.

Sibatani, A. (1950). Nature, Lond., 166, 355.

Simpson, W. L. (1941a). Anat. Rec., 80, 173. (1941b). Ibid., 80, 329.

Sneath, P. H. A. (1950). Nature, Lond., 166, 699.

Soulairac, A., Desclaux, P., and Teysseyre, J. (1949a). Ann. endocrinol., Paris, 10, 285. (1949b). Ibid., 10, 535 .

Stacey, M., Deriaz, R. E., Teece, E. G., and Wiggins, L. F. (1946). $\quad$ Nature, Lond., 157, 740.

Stafford, R. O., and Atkinson, W. B. (1948). Science, 107, 279.

Stedman, E., and Stedman, E. (1943a). Nature, Lond., 152, 267.

(1943b). Ibid., 152, 503. (1944). Ibid., 153, 500.

(1950). Biochem. J., 47, 508.

Stefano, H. S. di (1948). Chromosoma, 4, 282.

Stein, J. (1935). C.R. Soc. Biol., Paris, 120, 1136.

Stirling, W. (1875). J. Anat. Physiol., Lpz., 10, 185.

Stöhr, P. (1882). Arch. mikr. Anat., 20, 221.

Stowell, R. E. (1946). Stain Tech., 21, 137.

and Zorzoli, A. (1947). Ibid., 22, 51.

Struve, H. (1872). Liebig's Ann. Chem. Pharm., 163, 160.

Sulkin, N. M., and Kuntz, A. (1950). Proc. Soc. exp. Biol., N.Y., 73, 413.

Sylvén, B. (1941). Acta chir. scand., 86, Suppl. 66. (1945). Acta radiol., Suppl. 59 .

Szanto, P. B., and Popper, H. (1948). Bull. int. Ass. med. Mus., 28, 119.

Taft, E. B. (1949). Nature, Lond., 164, 1133.

Takamatsu, H. (1939). Trans. Soc. path. jap., 29, 492.

Thomas, L. E. (1946). J. cell. comp. Physiol., 28, 145.

Thomas, J. A., and Lavalloy, J. (1935). Bull. Histol. Tech. micr., 12, 400.

Tomasi, J. A. de (1936). Stain Tech., 11, 137.

Tulasne, R., and Vendrely, R. (1947). Nature, Lond., 160, 225.

Turchini, J., Castel, P., and Kien, K. V. (1944). Bull. Histol. Tech. micr., 21, 124.

Unna, P. G. (1887). Arch. mikr. Anat., 30, 39.

Vallance-Cwen, J. (1948). J. Path. Bact., 60, 325.

Vlès, F., and Ugo, A. (1936). C.R. Soc. Biol., Paris, 123, 226.

Vogel, J. (1845). Pathologische Anatomie des menschlichen Körpers. Leipzig.

(1847). Pathological Anatomy of the Human Body, trans. Day, G. E., p. $346 . \quad$ London.

Voss, H. (1940). Z. Zellforsch., 31, 43.

Wachstein, M. (1946). J. exp. Med., 84, 25.

and Zak, F. G. (1946). Proc. Soc. exp. Biol., N.Y., 62, 73.

Wadsworth, A., and Crowe, M. O'L. (1936). J. phys. Chem., 40, 739.

Wang, K. J., and Grossman, M. I. (1949). J. Lab. clin. Med., 34, 292.

Weigert, C. (1884). Fortschr. Med., 2, 190.

White, J. C. (1950). Proc. Biochem. Soc., Biochem. J., 47, 16.

Willstätter, R., and Rohdenwald, M. (1934). Hoppe-Seyl. Z., 225, 103.

Wislocki, G. B., and Dempsey, E. W. (1946). Anat. Rec., 96, 249.

Bunting, H., and Dempsey, E. W. (1947). Amer. J. Anat., 81, 1.

Rheingold, J. J., and Dempsey, E. W. (1949). Blood, 4, 562.

Zeiger, K. (1930). Z. Zellforsch., 10, 481. 